\title{
ANTIDUMPING INVESTIGATIONS AND THE PASS-THROUGH OF EXCHANGE RATES AND ANTIDUMPING DUTIES
}

\author{
Bruce A. Blonigen \\ Stephen E. Haynes \\ Working Paper 7378 \\ http://www.nber.org/papers/w7378 \\ NATIONAL BUREAU OF ECONOMIC RESEARCH \\ 1050 Massachusetts Avenue \\ Cambridge, MA 02138 \\ October 1999
}

This paper has benefitted greatly from comments received at the 1999 NBER Summer Institute. We thank Michael Gallaway for his help in obtaining data for this paper and Denice Gray for her excellent research assistance. Blonigen acknowledges support from NSF grant no. 9810706. Any errors or omissions are the sole responsibility of the authors. The views expressed herein are those of the authors and not necessarily those of the National Bureau of Economic Research.

(C) 1999 by Bruce A. Blonigen and Stephen E. Haynes. All rights reserved. Short sections of text, not to exceed two paragraphs, may be quoted without explicit permission provided that full credit, including $\mathbb{C}$ notice, is given to the source. 
Antidumping Investigations and the Pass-Through of

Exchange Rates and Antidumping Duties

Bruce A. Blonigen and Stephen E. Haynes

NBER Working Paper No. 7378

October 1999

JEL No. F13, F31, L11

\section{ABSTRACT}

We present a model that shows that exchange rate pass-through is likely to be substantially altered when firms face antidumping $(\mathrm{AD})$ duties and that optimal pass-through of $\mathrm{AD}$ duties may be up to 200 percent. We examine both pass-through issues using monthly prices across 345 U.S.imported Canadian iron and steel products from 1989 through 1995, some of which received duties in U.S. AD cases filed in 1992. We find that exchange rate pass-through rise dramatically after products received $\mathrm{AD}$ duties, with no such change for closely-related products not subject to final $\mathrm{AD}$ duties. This result has important implications for previous studies that have pooled $\mathrm{AD}$ and non$\mathrm{AD}$ products. We also find that pass-through of the final $\mathrm{AD}$ duties is 160 percent, which is consistent with our model's predictions.

Bruce A. Blonigen

Department of Economics 1285 University of Oregon

Eugene, OR 97403-1285

and NBER

bruceb@oregon.uoregon.edu
Stephen E. Haynes

Department of Economics 1285 University of Oregon Eugene, OR 97403-1285 shaynes@oregon.uoregon.edu 


\section{Introduction}

Economists in both international economics and industrial organization have committed substantial work to understanding the pricing behavior of exporting firms in the presence of variations in the exchange rate. The research has important implications ranging from understanding international adjustment under flexible exchange rates to firm behavior under price uncertainty. Much of this research has focused on the concept of exchange rate pass-through - how a firm alters the price of an exported good, denoted in the currency of the importing country, to a change in the exchange rate. A one-to-one response is defined as complete pass-through, and a less than one-to-one response is partial or incomplete pass-through. ${ }^{1}$

Research on exchange rate pass-through can be divided into two sets -- studies that explore cross-sectional variation in pass-through, and those that focus on time series variation. Both sets find that pass-through tends to be incomplete, with the fraction averaging about 60 percent (Goldberg and Knetter, 1997, p. 1250), and highly variable. Cross-sectional variation is primarily explained by industry characteristics, e.g., market power. Time series variation is usually explained by shifts in exchange rate expectations, e.g., whether exchange rate movements are expected to be permanent or transitory, and hysteresis effects. ${ }^{2}$

Curiously, there has been little research on trade protection policies in connection with exchange rate pass-through or even the pass-through of trade protection instruments. One exception is Feenstra

${ }^{1}$ As surveyed in Goldberg and Knetter (1997), pass-through studies are closely related to two other literatures: research on pricing-to-market, i.e., how an exporting firm price discriminates across destination countries given changes in exchange rates, and research into the law-of-one-price on international markets.

${ }^{2}$ See Knetter (1993), Feenstra, Gagnon, and Knetter (1996), Gron and Swenson (1996), and Yang (1996) for studies of industry effects on pass-through; and Baldwin (1988) and Froot and Klemperer (1989) for research on the effect of exchange rate expectations. 
(1989), which proposes and tests the hypothesis that ad valorem tariffs and exchange rate changes lead to symmetrically identical pass-through to prices. Interestingly, Feenstra(1989) examines the pass-through of tariffs and exchange rates individually, but not the potential impact of the trade policy on exchange rate pass-through. Harrison (1992)and Knetter (1994) examine this latter issue in the context of quantitative restrictions. Both Harrison and Knetter argue that pass-through of exchange rates (or pricing-to-market) depends on whether or not quantitative restrictions are binding. Knetter finds little evidence of pricing-tomarket for various Japanese and German exported products, including autos and certain steel products, while Harrison finds binding VERs substantially reduce exchange rate pass-through for U.S. imports of European steel, but not for Japanese steel.

In this paper we explore for the first time the impact of antidumping (AD) investigations on passthrough of both exchange rates and the $\mathrm{AD}$ duties. Arguably the most heavily-used trade restriction in recent years, $\mathrm{AD}$ protection policies lead to $\mathrm{AD}$ duties when a foreign firm is found to sell a good in a domestic market at "less than fair value," i.e., dumping, and causing "material injury" to domestic firms. Like quantitative restrictions, we show that this form of protection (and the administration procedures that accompany them) theoretically affects firms' exchange rate pass-through decisions, even though most economists typically view $\mathrm{AD}$ duties as standard ad valorem tariffs. An important difference relative to standard tariffs is that AD duties are potentially recalculated each year by the U.S. Department of Commerce (USDOC) based on the firm's previous-year pricing decisions in what are known as administrative reviews. This review process implies that $\mathrm{AD}$ duties are endogenously determined over time by the firms' pricing decisions in both its export market and own home market. The endogeneity has important implications for both exchange rate pass-through and the pass-through of the AD duty. In our model, we first show that $\mathrm{AD}$ duties and the resulting administrative review process may substantially alter exchange rate pass-through elasticities. Second, we demonstrate that optimal behavior by the firm 
may imply pass-through of up to 200 percent of the initial AD duty.

To test the effect of $\mathrm{AD}$ investigations on pass-through of exchange rates and $\mathrm{AD}$ duties, we examine monthly panel data of 345 iron and steel imports from Canada to the U.S. over the period 1989 to 1995. Our panel includes products that were involved in U.S. AD iron and steel cases filed in 1992, as well as other closely-related products that were not involved or received negative determinations. The period from 1989 to 1995 is judicious because it includes the timeline of events during the AD investigations. We choose U.S. iron and steel imports from Canada because many U.S. AD investigations involved iron and steel, and more iron and steel is imported into the U.S. from Canada than any other country except Japan. ${ }^{3}$ Canada was also one of the few significant import sources not subject to U.S. steel VRAs leading into the time period of our data (USITC, 1994, p. 90), which substantially eases concerns that these quantitative restrictions could confound our estimates of the effect of $\mathrm{AD}$ investigations on pass-through of exchange rates and $\mathrm{AD}$ duties.

Our estimates show significant differences in pass-through behavior between those products that received an AD duty and those that did not. Consistent with our model, we find that exchange rate passthrough rises dramatically for products once they become subject to final $\mathrm{AD}$ duties. In contrast, exchange rate pass-through for products that did not receive an $\mathrm{AD}$ duty remains constant over our entire sample. Also consistent with our model, we find that pass-through of the final AD duty is more than complete, as our estimates indicate pass-through of $160 \%$ of the initial duty.

Thus, our analysis shows that estimates of pass-through from incorrectly pooling affirmative and nonaffirmative products and/or ignoring structural breaks from $\mathrm{AD}$ final determinations leads to substantially biased coefficients. In fact, pass-through estimates for both exchange rates and the AD

${ }^{3}$ In 1992, 24 percent of total U.S. iron and steel imports (SIC 3312) came from Japan and 23 percent came from Canada. The next largest import source was Germany with about 8 percent import market share. 
duties for affirmative products after the $\mathrm{AD}$ final determination are double those from the pooled sample estimates. This has important implications for many previous studies of exchange rate pass-through or pricing-to-market in U.S. manufacturing industries, which ignore $\mathrm{AD}$ investigations involving the products or industries of interest. ${ }^{4}$ Indeed, since 1980 there have been over $800 \mathrm{AD}$ investigations with approximately half of these cases ruled affirmative against foreign imports, leading to significant duties. In addition to steel and steel-related products, these AD cases have spanned important manufacturing sectors including chemicals, semiconductors, computers, communications equipment, ball bearings, and other industrial machinery. In fact, Gallaway, Blonigen, and Flynn (forthcoming) concludes that duties from U.S. AD investigations (in combination with countervailing duties) are second only to the Multifiber Arrangement quotas in terms of net welfare costs to the U.S. economy. They also note that, while successive GATT rounds have substantially reduced tariffs and quantitative restrictions, AD procedures have not been substantially addressed by the WTO-member countries, and many countries are currently implementing their own $\mathrm{AD}$ programs that are patterned after the U.S. and EU. This suggests that $\mathrm{AD}$ protection will continue to grow in importance relative to other forms of protection.

The remainder of the paper is organized as follows. The next section summarizes the administration of U.S. AD investigations. Section 3 develops a model to explain how AD investigations and determinations may generally affect exchange rate pass-through. The rest of the paper tests the

\footnotetext{
${ }^{4}$ While this paper is the first to examine pass-through issues connected with AD investigations and duties, the tenor of our results is consistent with other previous studies that have shown that AD protection leads to many consequences beyond the standard effects of an ad valorem tariff. These studies include Staiger and Wolak (1994) and Krupp and Pollard (1996), which demonstrate the substantial effects that "investigation events" alone have on import and pricing behavior by investigated firms; Prusa (1997), which details trade diversion effects; Anderson (1992; 1993) and Rosendorff (1996), which model the political economy interactions with voluntary export restraints; and Feinberg (1989) which argues that the filings of complaints by U.S. companies alleging sales of imports at "less than fair value" is inversely related to the real external value of the U.S. dollar, suggesting that filings cannot be viewed as exogenous in equations like those estimated in this study.
} 
hypotheses from section 3 using the case of the 1992 U.S. AD investigations of Canadian iron and steel products. Thus, section 4 presents a brief history of these U.S. AD investigations, section 5 presents our empirical methodology, including discussion of the data, and section 6 presents and evaluates our empirical results. The final section summarizes our conclusions.

\section{Overview of U.S. antidumping investigation procedures}

The U.S. antidumping laws are administered by the U.S. Department of Commerce (USDOC) and the U.S. International Trade Commission (USITC), each with distinct roles in the process. When a petition is filed, the USDOC's role is to determine whether the subject product is being sold at "less than fair value" in the U. S. Specifically, they calculate whether firms exporting to the U. S. are selling the product in the U. S. at less than "normal" or "fair" value, which is generally defined as the foreign firm's own home market price for the same good. ${ }^{5}$ For each case, the USDOC calculates an ad valorem dumping margin equal to the percentage difference between the U.S. transaction prices they observe and "fair value". The USITC concurrently determines whether the relevant U.S. domestic industry has been materially injured, or is threatened with material injury, by reason of the imports subject to its investigation.

The USDOC and USITC each make preliminary and final determinations for each case. If an affirmative preliminary determination is made by both the USDOC and the USITC, then the importer must post a cash deposit, a bond or other security for each entry equal to the preliminary margin determined by the USDOC. This requirement stays in effect until either the USDOC or the USITC makes a negative final determination. If an affirmative final determination is made by both the USITC

${ }^{5}$ If home market sales are inadequate, then normal value is based on sale prices in third country markets. If third country sales are inadequate, then normal value is based on a constructed value for the foreign like product using manufacturing costs, selling, general and administrative costs, profits and packaging costs. 
and USDOC, then the USDOC issues an AD order to levy a duty equal to the estimated dumping margin on the subject product. When a subject foreign product enters the U. S., the importer must pay U.S. Customs a cash deposit equal to the margin times the value of the subject product. However, these cash deposits do not necessarily represent the final amount of duties to be assessed on the subject imports. Rather, the margin determined in the USDOC's final investigation is only used as a basis for estimating the duty liability of the importer. The actual liability of the importer may be determined in subsequent years by the USDOC. Before 1984, this was accomplished by automatic yearly administrative reviews by the USDOC. However, since 1984, such reviews have become voluntary; that is, unless an interested party requests a review, the duties assessed are those found in USDOC's final determination (or most recent administrative review). Every year, on the anniversary of the date the final AD duties were assessed, the USDOC asks for any requests by interested parties for an administrative review of a firm's $\mathrm{AD}$ duty. A request may come from a foreign firm which faces the duty or an interested U.S. firm or organization. The purpose of an administrative review is to adjust the margin on subject imports to reflect changes in the difference between the foreign firm's U.S. price and their normal value. The USDOC typically recalculates the dumping margin for the previous 12 months immediately preceding the administrative review request. Once USDOC calculates a dumping margin over this period, a duty equal to the newly calculated dumping margin replaces any previously-existing duty. If a subsequent review determines that the margin during the review period is different from the previous margin used as a basis for the importer's cash deposit, a bill (or refund) in the amount of the difference plus interest is assessed (or rebated). The administrative review process thus allows foreign firms to discontinue any dumping into the U.S. and subsequently have the duty removed. This process is crucial to understanding why AD duties are quite distinct from standard ad valorem tariffs.

Given our paper's focus on exchange rate pass-through, it is important to note that in 
determination of dumping margins the USDOC uses (when available) the daily bilateral exchange rate of the subject country at the time of the U.S. transactions it is using for calculating the dumping margin. However, when a daily rate represents a sizeable fluctuation, defined as $2.25 \%$ different from a rolling average of rates for the past 40 business days (referred to as the "benchmark rate"), the USDOC then uses the "benchmark rate". 6

\section{Model}

Feenstra (1989) presents a model that derives the optimal pricing decision for a monopolist exporting firm and examines pass-through of ad valorem tariffs and exchange rates. Consideration of $\mathrm{AD}$ duties requires an extension of Feenstra's model because AD duties are endogenous to the firm's pricing decisions in both its own home market and its export market through the administrative review process. Thus, we begin by introducing a model with demand for the firm from two markets, the home and foreign (export) markets. After examining a benchmark model with no AD duty, we examine the case where the firm faces an $\mathrm{AD}$ duty in which the foreign country defines "fair value" as the price charged by the firm in its own home market. We first compare pass-through of exchange rates with and without $\mathrm{AD}$ duties and find that these exchange rate pass-through effects may be quite different. The theory is ambiguous on the difference in magnitude of these two effects, leaving the question open for our empirical analysis. Second, we show that the change in the foreign market price with respect to an $A D$ duty is necessarily different than an equivalent ad valorem tariff. In fact, we show that pass-through of the AD duty may be as large as 200 percent of the initial duty.

${ }^{6}$ In the 1992-93 U.S. steel cases this adjustment to a benchmark rate was not used. For smaller and less-developed countries, daily rates are often not readily available. In those cases the USDOC uses average monthly averages, as reported by the International Monetary Fund. 


\subsection{The benchmark model - no AD duty}

To begin, we set up a simple model of a discriminating monopolist in two markets: its home $(\mathrm{H})$ market and the foreign (F) market to which it exports. ${ }^{7}$ We assume that the firm faces demand of $\mathrm{x}^{\mathrm{H}}\left(\mathrm{p}^{\mathrm{H}}, \mathrm{I}^{\mathrm{H}}\right)$ in its home market and $\mathrm{x}^{\mathrm{F}}\left(\mathrm{p}^{\mathrm{F}}, \mathrm{I}^{\mathrm{F}}, \mathrm{q}^{\mathrm{F}}\right)$ in the U.S. market. Both functions are assumed continuous and twice differentiable. $\mathrm{I}^{\mathrm{H}}$ and $\mathrm{I}^{\mathrm{F}}$ represent income (or equivalently, expenditure on all goods) by consumers in each market. Inclusion in the demand functions in this manner assumes that for both markets demand is weakly separable from other goods in the consumer's utility function. Demand in the U.S. market, $\mathrm{x}^{\mathrm{F}}($.$) , is an import demand function, where we assume the foreign firm faces a domestic$ substitute product, $\mathrm{q}^{\mathrm{F}}$. Assuming the exporting firm and domestic producers in the foreign market play a Bertrand game, we can treat $\mathrm{q}^{\mathrm{F}}$ as an exogenous parameter. ${ }^{8}$ Demand is downward-sloping in the good's own price in both markets. All production occurs in the firm's home market with a twice differentiable and continuous cost function, $\ddot{\mathrm{o}}\left(\mathrm{x}^{\mathrm{H}}+\mathrm{x}^{\mathrm{F}}, \mathrm{w}\right)$, where $\mathrm{w}$ represents home factor prices. As in Feenstra (1989), we assume the firm sets its export price in the foreign currency, but maximizes profits in its own currency.

Given these assumptions, the firm's problem in this benchmark model is the following:

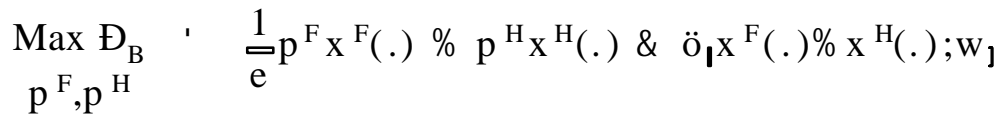

7 This model follows Boltuck (1987) closely, though we employ many of Feenstra's (1989) assumptions and notation.

${ }^{8} \mathrm{We}$ assume there is only one firm producing in the foreign firm's home market and thus do not include a $\mathrm{q}^{\mathrm{H}}$ term in the $\mathrm{x}^{\mathrm{H}}($.) demand function. This assumption is due to data constraints in our empirical work below in that we only have data on product prices, not firm-level prices. 
where $\mathrm{e}$ is the expected bilateral exchange rate expressed as foreign market currency to home market currency. ${ }^{9}$ First-order conditions for this problem can be expressed as:

$$
\begin{array}{ll}
p^{\mathrm{F}}: & (1 / \mathrm{e})\left(\mathrm{p}^{\mathrm{F}} \% \mathrm{p}^{\mathrm{F}} \mathrm{c}^{\mathrm{F}}\right) \& \ddot{o}^{\prime} \mathrm{c}^{\mathrm{F}} / 0 \\
\mathrm{p}^{\mathrm{H}}: \mathrm{p}^{\mathrm{H}} \% \mathrm{p}^{\mathrm{H}} \mathrm{c}^{\mathrm{H}} \& \ddot{o}^{\prime} \mathrm{c}^{\mathrm{H}} / 0
\end{array}
$$

where $c^{\mathrm{F}}$ and $c^{\mathrm{H}}$ are the firm's own-price elasticities of demand in the foreign and its home markets, respectively. Assuming second-order conditions are satisfied, we can solve for optimal prices, $\mathrm{p}^{\mathrm{F}^{\prime}} \mathrm{p}\left({ }^{\mathrm{F}}\left(\mathrm{w}, \mathrm{e}, \mathrm{q}^{\mathrm{F}}, \mathrm{I}^{\mathrm{F}}, \mathrm{I}^{\mathrm{H}}\right)\right.$ and $\mathrm{p}^{\mathrm{H}^{\prime}} \mathrm{p}\left({ }^{\mathrm{H}}\left(\mathrm{w}, \mathrm{e}, \mathrm{q}^{\mathrm{F}}, \mathrm{I}^{\mathrm{F}}, \mathrm{I}^{\mathrm{H}}\right)\right.$. Feenstra (1989) shows in that paper's model that the response of the price of the export to changes in the exchange rate, factor costs, price of the domestic good, and income depends on the nature of costs and demand. As with Feenstra, the presence of increasing marginal costs and a price elasticity of demand that declines in price is sufficient in our model to generate what the literature considers "normal" comparative static results. In summary, given these conditions, our model implies that the price of the export to the foreign market increases in factor costs, income in the foreign country, the price of the domestic substitute good, and an appreciation of the exporting firm's home currency. ${ }^{10}$

However, because of our model's additional consideration of the exporting firm's home market, the magnitudes of the comparative static results may differ from those of the Feenstra model. Changes in parameters that directly affect only one market (such as, $\mathrm{I}^{\mathrm{F}}$ ) will affect optimal prices for the firm in both

${ }^{9}$ Following Feenstra (1989), we assume that all other variables are non-random. This assumption, in conjunction with our assumption that the firm sets price in the foreign market currency, allows us to set up the profit maximization in the certainty-equivalent fashion in (1) where e denotes the expected exchange rate.

${ }^{10}$ These conditions are also sufficient to satisfy the second-order conditions. The comparative static result with respect to income requires the additional condition that the income elasticity of demand for the good in the foreign market is constant for all prices. These conditions also mean an increase in the income of the home country will increase the price charged in the foreign country. These comparative static results are available from the authors upon request. 
markets through the cost function, provided marginal costs are not constant. Given this paper's focus, the effect of exchange rate changes on the optimal price in the foreign market (i.e., pass-through) is of most interest. Using the implicit function theorem, we first derive the effect of the exchange rate on the exporting firm's prices:

$$
\begin{aligned}
& \frac{M{ }^{F}}{N} *_{B}^{\prime}, \frac{\left(1 / e^{2}\right)\left(1 \% c^{F}\right)\left(N D_{B} / \phi^{H^{2}}\right.}{D_{B}}>0 \\
& \frac{M^{\mathrm{H}}}{\mathrm{N}} *_{\mathrm{B}}, \frac{\&\left(1 / \mathrm{e}^{2}\right)\left(1 \% c^{\mathrm{F}}\right)\left(\mathrm{M \boxplus}_{\mathrm{B}} / \mathrm{M}^{\mathrm{F}} \mathrm{M \phi}^{\mathrm{H}}\right.}{\mathrm{D}_{\mathrm{B}}}
\end{aligned}
$$

where $D_{B}$ is the determinant of the Hessian for this benchmark model and positive by the second-order condition. Equation (3a) shows that the pass-through of the exchange rate on the foreign price is positive. To see this, note that from the first-order conditions in $(2),\left(1 / \mathrm{e}^{2}\right)\left(1+\mathrm{c}^{\mathrm{F}}\right)$ must be negative in sign. Also, the second term in the numerator must be negative, provided the firm would face a well-behaved maximization problem if it sold to only the home market. ${ }^{11}$

Equation (3b) implies that the exchange rate change can impact the price charged by the exporting firm in its home market as well. The sign of the effect of an exchange rate change on the

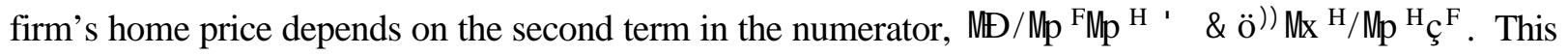
term is obviously negative if marginal costs are increasing in output, zero if marginal costs are constant, and positive if marginal costs are decreasing. Thus, the optimal home price for the firm decreases with an exchange rate appreciation of the home currency when marginal costs are increasing in output, is unchanged when marginal costs are constant, and increases if marginal costs are decreasing. ${ }^{12}$

${ }^{11}$ In other words, this term would need to be negative in order to satisfy second-order sufficient conditions were the firm to only sell in its own market.

12 This result has important implications for pass-through studies that examine only movements in the price in the export market and wish to relate those back to the law of one price. For example, if 


\subsection{Model of firm pricing decision in the presence of an $A D$ duty}

Given the benchmark model of a price discriminating firm above, we now examine this firm's optimal pricing decisions when it becomes subject to an AD duty and the administrative review process. After laying out the firm's new objective function, we compare exchange rate pass-through for the firm facing the $\mathrm{AD}$ duty versus our benchmark model above, where the firm faces no such $\mathrm{AD}$ duty.

Assume the firm has just been found to be dumping and receives an initial $\mathrm{AD}$ duty, $\mathrm{t}_{0}^{\mathrm{AD}}$. As mentioned in section 2, this initial AD duty is only an "estimate" of the duty the firm must pay over the coming period until an administrative review recalculates a dumping margin. The actual AD duty paid by the firm will be the dumping margin calculated by the USDOC at the end of the period and applied ex post. That is, an administrative review by the USDOC evaluates the previous year's prices in both markets to determine an ex post $\mathrm{AD}$ duty for the previous one-year period. If the ex post $\mathrm{AD}$ duty is less than the $\mathrm{AD}$ duty charged to the firm during the previous year, the firm receives a refund. ${ }^{13}$ If the $e x$ post $\mathrm{AD}$ duty is greater than $\mathrm{t}_{0}^{\mathrm{AD}}$, then the firm must pay the difference on the past year's sales. We examine the case where the USDOC defines the firm's home price as "fair value" in its calculation of the dumping

margin, both at the time of the case and in subsequent administrative reviews. ${ }^{14}$ More specifically, "fair

marginal costs are increasing, one may observe only partial pass-through in the export market even though the law of one price may hold because the exporting firm's home price declined by the requisite amount! This is a simple, but interesting, result that comes out of this model that considers both of the firm's markets.

${ }^{13}$ We assume a discount factor of one. This simplifies the model and is potentially consistent with reality because additional payments or refunds by firms of $\mathrm{AD}$ duties includes interest.

14 This is the USDOC's most preferred method for determining "fair value", unless there is insufficient sales by the investigated firm in the foreign market or the foreign market is not a market economy. Also, this was the proxy measure used by the USDOC in the Canadian steel cases and 
value" is defined as the price observed in the foreign market once it is converted into the exporting firm's own currency and net of any original estimated $\mathrm{AD}$ duty, $\mathrm{t}_{0}^{\mathrm{AD}}$, in place at the beginning of the period.

Given this definition of fair value and the method of determining the AD duty ex post, it is easy to see that the effective $\mathrm{AD}$ duty $\left(\mathrm{t}_{\mathrm{E}}^{\mathrm{AD}}\right)$ is endogenous with the firm's pricing decisions over the period and takes the following form:

$$
\mathrm{t}_{\mathrm{E}}^{\mathrm{AD}} / \mathrm{p}^{\mathrm{H}} \& \mathrm{p}^{\mathrm{F}} /\left[\mathrm{e}\left(1 \% \mathrm{t}_{0}^{\mathrm{AD}}\right)\right]
$$

whenever the expression in (4) is positive and zero otherwise. Thus, the firm's maximization problem immediately after a final determination, which takes into account the administrative review process, is

the following:

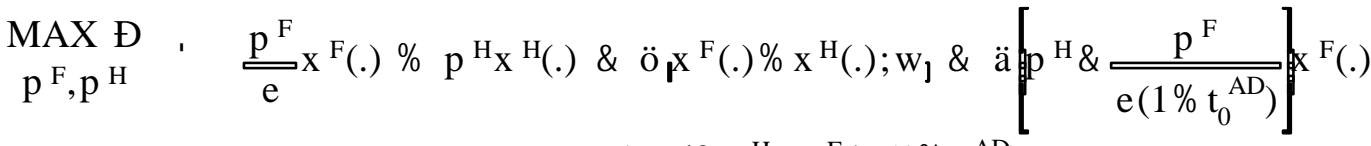

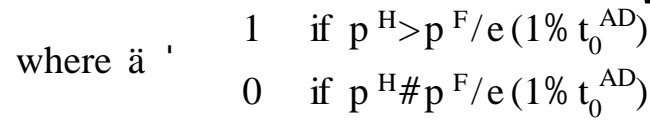

Assuming second-order conditions are satisfied, we can solve for optimal prices in the presence of an AD duty:

$$
\begin{array}{ll}
p^{F}{ }^{\prime} & p\left({ }^{F}\left(e, w, t_{0}{ }^{A D}, q^{f}{ }^{f} I^{F}, I^{H}\right)\right. \\
p^{H}{ }^{H} & p\left({ }^{H}\left(e, w, t_{0}{ }^{A D}, q^{f}, I^{~}{ }^{F}, I^{H}\right)\right.
\end{array}
$$

The firm's problem then divides into three possible cases in equilibrium:

subsequent administrative reviews, as well as the steel cases and reviews involving firms from other developed countries. 
Case $1: \mathrm{p}^{\mathrm{H}}>\mathrm{p}^{\mathrm{F}} / \mathrm{e}\left(1 \% \mathrm{t}_{0}^{\mathrm{AD}}\right)$

Case $2: \mathrm{p}^{\mathrm{H}} \cdot \mathrm{p}^{\mathrm{F}} / \mathrm{e}\left(1 \% \mathrm{t}_{0}^{\mathrm{AD}}\right)$

Case $3: \mathrm{p}^{\mathrm{H}}<\mathrm{p}^{\mathrm{F}} / \mathrm{e}\left(1 \% \mathrm{t}_{0}{ }^{\mathrm{AD}}\right)$

Since we are examining the problem from the perspective of a firm that has been found in the previous period to be dumping by the definition in (4), it is unlikely that case 3 will be relevant unless the market environment has changed drastically. Therefore, we concentrate on case 1 and 2.

\subsubsection{Model with AD duty - case 1.}

In case 1 , the firm does not change its prices in a way to completely eliminate the effective AD duty. This means $\ddot{a}=1$ in equation (5). Rearranging, we can write the firm's maximization problem as

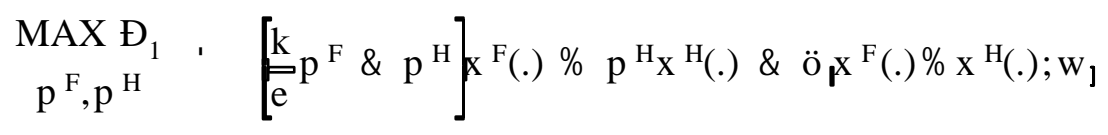

where $\mathrm{k}^{\prime}\left(2 \% \mathrm{t}_{0}^{\mathrm{AD}}\right) /\left(1 \% \mathrm{t}_{0}^{\mathrm{AD}}\right)>1$. First-order conditions for this maximization problem can be written as

$$
\begin{aligned}
& \left.\mathrm{p}^{\mathrm{F}}:(\mathrm{k} / \mathrm{e}) \mathrm{p}^{\mathrm{F}} \%(\mathrm{k} / \mathrm{e}) \mathrm{p}^{\mathrm{F}} \mathrm{c}^{\mathrm{F}} \& \ddot{o}\right)^{\mathrm{F}}{ }^{\mathrm{F}} \& \mathrm{p}^{\mathrm{H}} \mathrm{c}^{\mathrm{F}} / 0 \\
& \mathrm{p}^{\mathrm{H}}: \& \mathrm{p}^{\mathrm{H}} \frac{\mathrm{X}^{\mathrm{F}}}{\mathrm{x}^{\mathrm{H}}} \% \mathrm{p}^{\mathrm{H}} \% \mathrm{p}^{\mathrm{H}} \mathrm{ç}^{\mathrm{H}} \& \ddot{\mathrm{o}}{ }^{\mathrm{C}} \mathrm{c}^{\mathrm{H}} / 0
\end{aligned}
$$

Using the implicit function theorem, the effects of the exchange rate on the exporting firm's prices in case 1 are 


$$
\begin{aligned}
& \frac{\mathrm{\phi}^{\mathrm{F}}}{\mathrm{N}} *_{1}, \frac{\left(\mathrm{k} / \mathrm{e}^{2}\right)\left(1 \% \mathrm{c}^{\mathrm{F}}\right)\left(\mathrm{MP}_{1} / \mathrm{M \phi}^{\mathrm{H}^{2}}\right.}{\mathrm{D}_{1}}>0 \\
& \frac{M^{\mathrm{H}}}{\mathrm{N}} *_{1}, \frac{\&\left(\mathrm{k} / \mathrm{e}^{2}\right)\left(1 \% c^{\mathrm{F}}\right)\left(\mathrm{MP}_{1} / \mathrm{M}^{\mathrm{F}} \mathrm{M \phi}^{\mathrm{H}}\right.}{\mathrm{D}_{1}}
\end{aligned}
$$

As with the benchmark model, an exchange rate appreciation of the home currency to the foreign currency increases the firm's optimal price in the foreign market and a change in the home price that depends on the second derivative of the cost function.

While both the benchmark and case 1 models show that the foreign price increases with an exchange rate appreciation, one focus of our paper is to examine the difference between exchange rate pass-through before an AD duty is in place (benchmark model) to after it is imposed (case 1 model). To examine this difference, one can compare the comparative static results in equations (10a) and (10b) to equations (3a) and (3b), scaled into elasticities by the ratio of the exchange rate to the equilibrium price. Intuition might suggest that exchange rate pass-through would increase with the AD duty in place: If the exchange rate appreciates and the firm does not fully pass-through the change to foreign prices, the firm will appear to be dumping to an even greater extent. However, the dumping margin calculation also includes the firm's home price. Thus, relative demand conditions across the two markets (home and foreign) become more important for comparative static effects in the case 1 model than in the benchmark model, where the only potential interdependence is through the cost function. These relative demand conditions can mitigate and even reverse the standard intuitive incentive for the firm to more fully passthrough exchange rate changes when facing an $\mathrm{AD}$ duty. In general, the exchange rate pass-through elasticity in case 1 may be either smaller or larger than in the benchmark case, and we show in the appendix that this is true even for the simple case of linear demand and constant marginal costs. Thus, imposition of an $\mathrm{AD}$ duty may cause a change in the exchange rate pass-through, but we must turn to the 
data to understand both the direction and magnitude of the exchange rate pass-through elasticity.

A second issue we explore with both the model and our data is the pass-through of the AD duty. It is easy to see from first-order conditions that an $\mathrm{AD}$ duty, with an original ad valorem duty of $\mathrm{t}_{0}^{\mathrm{AD}}$ and an administrative review process connected with it, will impact the foreign price in a different manner than a standard ad valorem tariff of $\mathrm{t}_{0}^{\mathrm{AD}}$. The first-order conditions of the benchmark model with a standard ad valorem tariff of $\mathrm{t}_{0}^{\mathrm{AD}}$ are:

$$
\begin{aligned}
p^{F} & :\left[1 / e\left(1 \%{ }_{0}^{A D}\right)\right]\left(p^{F} \% p^{F} c^{F}\right) \& \ddot{o}^{\prime} c^{F} / 0 \\
p^{H} & : p^{H} \% p^{H} c^{H} \& \ddot{o}^{\prime} c^{H} / 0
\end{aligned}
$$

whereas the first-order conditions in (9) can be rewritten as:

$$
\begin{aligned}
p^{F} & : p^{F} / e \%\left[\left(p^{F} / e\right) \& p^{H}\right] c^{F} \%\left[1 / e\left(1 \% t_{0}^{A D}\right)\right]\left(p^{F} \% p^{F} c^{F}\right) \& \ddot{o}^{\prime} c^{F} / 0 \\
p^{H} & : \& p^{F}\left(x^{H} / x^{F}\right) \% p^{H} \% p^{H} c^{H} \& \ddot{o}{ }^{H} c^{H} / 0
\end{aligned}
$$

Equality (12a) differs from (11a) by the first two terms in (12a), both of which are positive. And (12b) includes an additional first term compared to (11b), which is negative. Thus, it can be shown that, for the "standard" case of constant or increasing marginal costs and a price elasticity of demand that declines in price, the increase in the equilibrium foreign price from the benchmark model (and the decrease in the equilibrium home price) will be greater in the case of an initial $\mathrm{AD}$ duty of $\mathrm{t}_{0}^{\mathrm{AD}}$ than a standard $a d$ valorem tariff of $\mathrm{t}_{0}^{\mathrm{AD}}$. The intuition behind this result is straightforward. The administrative review process gives the firm added incentive to raise the foreign price and lower the home price to effectively lower the duty it faces, which go beyond the normal pass-through effects on the firm's revenues and operating costs. In fact, it is easy to see that the firm may optimally choose to pass-through the AD duty by more than 100 percent onto the foreign price because the AD duty is calculated as the difference 
between the home price and the foreign price net of the AD duty. Thus, if the firm does not change its home price, the firm would have to raise its foreign price by 200 percent to eliminate the duty. Of course, the firm is likely to reduce its home price to help eliminate the duty, in which case pass-through to the export price will be less than 200 percent even if we observe elimination of the duty. Our empirical analysis below of $\mathrm{AD}$ duty pass-through with firms that virtually eliminated their $\mathrm{AD}$ duty will allow us to estimate the magnitude of this pass-through to the export market for these cases. ${ }^{15}$

\subsubsection{Model with AD duty - case 2.}

We next consider case 2, where the firm is essentially at a corner solution of charging a price in the foreign market, such that it equals the USDOC definition of "fair value". In this case, $\ddot{a}=0$ in equation (5) and we can substitute the following equality into our firm's profit maximization function:

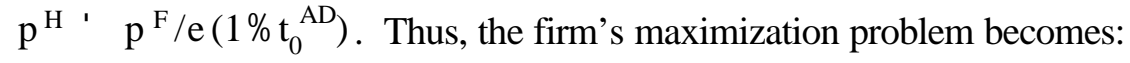

$$
\underset{p^{F}}{\operatorname{MAX} \oplus_{2}} \quad \frac{p^{F}}{e} x^{F}(.) \% \frac{p^{F}}{e\left(1 \% t_{0}^{A D}\right)} x^{H}(.) \& \ddot{o}_{p} X^{F}(.) \% X^{H}(.) ; w_{]}
$$

First-order conditions for this maximization problem can be written as

$$
\left.p^{F}:(1 / e) p^{F} \%(1 / e) p^{F} c^{F} \& \ddot{o}^{\prime}\right) c^{F} \% \frac{\hat{k}}{e}\left[p^{F} \underset{x^{F}}{x^{H}} \% \frac{\hat{k}}{e} \frac{M^{H}}{M^{F}} \frac{p^{F}}{x^{F}} \& \ddot{o} \frac{M^{H}}{M^{F}}\right] / 0
$$

where $\hat{\mathrm{k}}^{\prime} 1 /\left(1 \% \mathrm{t}_{0}^{\mathrm{AD}}\right)<1$. Assuming the second-order sufficient conditions hold, we can solve for the

${ }^{15}$ See Boltuck (1987) and Gallaway, Blonigen, and Flynn (forthcoming) for a more detailed discussion of the market conditions that determine the magnitude of pass-through of the AD duty to the foreign market and the magnitude of the decline in the home market price. 
optimal foreign price and, by definition, the optimal home price. By the implicit function theorem, the case 2 effects of the exchange rate on the exporting firm's foreign price (and the home price by the equality constraint) are

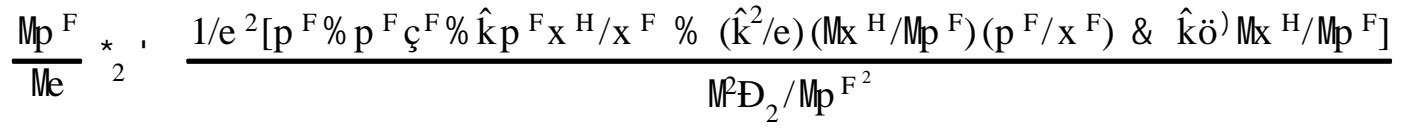

$$
\begin{aligned}
& \frac{\mu^{\mathrm{H}}}{\mathrm{N}} *_{2}, \frac{\mathrm{\phi}^{\mathrm{F}}}{\mathrm{N}}{ }_{2} \& \frac{\hat{\mathrm{k}} p^{\mathrm{F}}}{\mathrm{e}^{2}}
\end{aligned}
$$

These comparative static results hold provided a small change in the exchange rate does not cause the firm to alter its prices, such that the equality $\mathrm{p}^{\mathrm{H}}{ }^{\prime} \mathrm{p}^{\mathrm{F}} / \mathrm{e}\left(1 \% \mathrm{t}_{0}^{\mathrm{AD}}\right)$ no longer holds. It is possible that the parameters of the model are such that for the given exchange rate, e, the equality just holds. In this case, an appreciation of the exchange rate (i.e., a higher e) will lead to $\mathrm{p}^{\mathrm{H}}>\mathrm{p}^{\mathrm{F}} / \mathrm{e}\left(1 \% \mathrm{t}_{0}^{\mathrm{AD}}\right)$ and, thus, the relevant comparative statics are those in equations (10a) and (10b). In contrast, a depreciation of the exchange rate in this case will mean the relevant comparative static results are those in equations (15a) and (15b). In this particular case, there is an asymmetric response provided (15a) and (15b) differ from (10a) and (10b). ${ }^{16}$

Our main focus again is whether these optimal price responses to exchange rate changes in case 2 differ in magnitude from those with the benchmark case of no AD duty in place. As with case 1 , the change in the exchange rate pass-through effect may be larger or smaller in case 2 compared to the benchmark of no AD duty process. As with the comparison between case 1 and the benchmark model, we show in the appendix that the difference in exchange rate pass-through elasticities between case 2

${ }^{16}$ In our data, we found no evidence of asymmetric responses with respect to exchange rate appreciation versus depreciation, so we do not think this case is relevant for our data. 
and the benchmark model is ambiguous even for the case of linear demand and constant marginal costs.

In summary, we have shown that the presence of an $\mathrm{AD}$ duty substantially alters the objective function for a firm beyond that of a simple exogenous ad valorem tariff. Therefore, the theory shows that the presence of an $\mathrm{AD}$ duty has potentially important implications for pass-through effects of exchange rate changes on prices to the both markets served by the firm. ${ }^{17}$ Secondly, the model suggests that passthrough of an $\mathrm{AD}$ duty will be larger than for an equivalent standard tariff and could be as high as 200 percent. We next turn to analysis of the U.S. AD cases in Canadian iron and steel products to quantify these implications.

\section{A brief history of the U.S. AD cases in iron and steel products filed in 1992}

Our analysis of how AD investigations may affect exchange rate pass-through focuses on the U.S. antidumping investigation of imported iron and steel products that were filed in 1992 and its subsequent effect on U.S.-imported Canadian steel prices. Figure 1 outlines a timeline of important events during the U.S. 1992-93 AD steel cases. On June 8 of 1992, a group of U.S. steel producers filed an antidumping petition against a wide range of iron and steel products covered under chapter 72 of the Harmonized Tariff System (HTS) involving foreign producers from twenty different countries. ${ }^{18}$ For the

${ }^{17}$ Firms may view the problem of pricing in the presence of an AD duty as a multi-period problem, which we do not explore here. For example, the firm may want to completely eliminate the AD duty over time, but does so incrementally over a number of periods. It is unclear how this would affect the firm's exchange rate pass-through behavior in that model relative to the one we present. However, we note that in the U.S. steel cases presented in table 1, and particularly with the Canadian data we use in the empirical analysis below, firms generally received duties close to zero after just the first administrative review. This supports our modeling of only one review in our objective function.

${ }^{18}$ The petitioning U.S. firms were ARMCO Steel Co. L.P., Bethlehem Steel Corp., Geneva Steel, Gulf States Steel Inc. of Alabama, Inland Steel Industries Inc., LaClede Steel Co., LTV Steel Co. Inc., Lukens Steel Co., National Steel Corp., Sharon Steel Corp., USX Corp., U.S. Steel Group, and WCI Steel Inc. The investigated foreign firms were from Argentina, Australia, Austria, Belgium, Brazil, Canada, Finland, France, Germany, Italy, Japan, Korea, Mexico, the Netherlands, Poland, Romania, Spain, 
purposes of the investigation, the USITC categorized these products into four different groups which were each separately investigated with respect to the "material injury" determination: 1) cut-to-length carbon steel plate, 2) hot-rolled carbon steel plate, 3) cold-rolled carbon steel plate, and 4) corrosion-resistant carbon steel sheet. ${ }^{19}$ On February 4, 1993, the USDOC announced preliminary dumping margins which ranged from $0.88 \%$ to $109.22 \%$, with an average margin across the country-product cases of $33.23 \%$. Thus, effective February 4, 1993, investigated firms were required by U.S. Customs to post a cash deposit, a bond, or other security equal to the preliminary dumping margin for all subject merchandise subsequently imported into the United States. On July 9, 1993, the USDOC issued its final dumping margins which were very similar to its preliminary margins. ${ }^{20}$ On August 18, 1993, the USITC ruled its final determination. Unlike the USDOC, the USITC did not rule affirmative on all remaining cases. Of the 42 remaining country-product cases, the USITC ruled affirmative on 20 cases, primarily on cut-tolength carbon steel plate and corrosion-resistant carbon steel sheet. The remaining cases were ruled negative and cash deposits (or bonds and/or other securities) that were collected during the investigation since the preliminary USDOC margin determination were refunded (returned) to the importers.

As described in section 2, calculation of antidumping duties is an ongoing process through the administrative review procedures followed in U.S. AD cases. With respect to the steel cases, nineteen firms from Korea, Canada, Australia, Finland, Sweden, Germany, and the Netherlands requested administrative reviews of their dumping margins on the first anniversary of the case in 1994. While the

Sweden, Taiwan, and the United Kingdom.

${ }^{19}$ On August 21 of 1992, the USITC ruled "negative" on preliminary determinations with respect to cold-rolled carbon steel plate from Australia, Taiwan and the United Kingdom; hot-rolled carbon steel plate from Italy; cut-to-length carbon steel plate from Japan; and corrosion-resistant carbon steel sheet from Taiwan. This ended the investigations for these products.

${ }^{20}$ There were a few cases where preliminary USDOC dumping margins were amended prior to the final USDOC margin determination. 
petitions were initiated by the foreign firms, the original domestic petitioning steel firms also participated heavily in these administrative reviews. With the exception of Broken Hill Propriety Co. from Australia, all reviewed firms received substantially lower margins, with many reduced to almost zero. This suggests that these firms changed their behavior to eliminate any dumping over the period reviewed. ${ }^{21}$

The Canadian firms were in the group of firms that asked for administrative reviews and, as shown in table 1 , all had reduced their $\mathrm{AD}$ duty to less than $2 \%$ by the first administrative review. This means the Canadian firms were aggressive in eliminating the $\mathrm{AD}$ duty and suggests they are an appropriate focus for our examination of altered pricing behavior from the $\mathrm{AD}$ investigation and administrative review process. It is important to note that although the first administrative review began in August 1994, the final determination of new AD duties from this first review was not announced until March 1996. ${ }^{22}$ Thus, we assume in our analysis below that Canadian firms faced the same market conditions and incentives from the end of the AD case in August 1993 through at least the end of 1995, the end of our data sample. ${ }^{23}$

${ }^{21}$ Interestingly, many foreign firms with duties did not petition for an administrative review. Many of these were firms did not supply information in the original investigation and thus received dumping margins calculated using the "best information available" or BIA, which is often the data supplied by the domestic petitioners. This includes the Japanese and U.K. firms, as well as firms from less-developed countries.

22 The U.S. steel AD determinations with respect to Canadian firms were also being reviewed by a binational Canada-U.S. panel, as authorized by the U.S.-Canada Free Trade Agreement, from September 1993 through 1996. Our reading of the various Federal Register notices connected with the case suggest these binational panel reviews led to no significant changes in the U.S. steel case determinations during our sample period.

${ }^{23}$ For example, if the results of the first administrative review were determined in mid-1995 by the USDOC, this would establish "new" initial AD duties in our data and imply another change in the objective function faced by the firms, and hence new effects of the AD duties on exchange rate passthrough. Thus, we would have to be testing for an additional structural break in exchange rate passthrough beginning in mid-1995. 


\section{Empirical implementation}

\subsection{Specification and Tests}

As detailed below, our bilateral sample is disaggregate U.S. iron and steel imported products from Canada. Modifying our notation to reflect the bilateral U.S.-Canadian sample (and suppressing for simplicity the time and cross-section subscripts), our initial log-linear estimation equation that permits examination of the impact of an $\mathrm{AD}$ duty on pricing behavior follows from equation (6a): ${ }^{24}$

$$
\begin{gathered}
+\quad+\quad+\frac{+}{+} \quad+\quad+\quad ? \\
\ln \mathrm{p}^{\mathrm{US}}=\mathrm{f}\left[\ln \mathrm{e}, \ln \left(1+\mathrm{t}_{0}{ }^{\mathrm{AD}}\right), \ln \left(1+\mathrm{t}^{\mathrm{T}}\right), \ln \mathrm{w}, \ln \mathrm{q}^{\mathrm{US}}, \ln \mathrm{I}^{\mathrm{US}}, \ln \mathrm{I}^{\mathrm{CAN}}\right],
\end{gathered}
$$

where expected signs of coefficients are summarized above the regressors; $\mathrm{p}^{\mathrm{US}}$ is the U.S. dollar price of U.S. iron and steel imports from Canada; $\mathrm{e}$ is the U.S. dollar price of the Canadian dollar; $\mathrm{t}_{0}^{\mathrm{AD}}$ is the initial antidumping duty; $\mathrm{t}^{\mathrm{T}}$ is the ad valorem tariff; $\mathrm{w}$ is an aggregate of home factor costs proxied by Canadian producer costs in Canadian dollars; $q^{\mathrm{US}}$ is U.S. dollar price of the U.S. substitute good; $\mathrm{I}^{\mathrm{US}}$ is U.S. expenditures on steel in U.S. dollars; and $\mathrm{I}^{\mathrm{CAN}}$ is Canadian expenditures on steel in Canadian dollars.

We also consider specifications of (16) that include structural breaks, as suggested by our comparison of the benchmark model to the case 1 and case 2 models in section 3 . The coefficient on the exchange rate is our estimate of exchange rate pass-through. One empirical focus is to explore how, if at all, this coefficient is influenced by the AD duty. Other than the simple exercise of comparing estimates of (16) with and without $\mathrm{t}_{0}{ }^{\mathrm{AD}}$, we explore the impact of the AD duty by identifying exchange rate passthrough across two dimensions of our panel. One dimension is to distinguish between iron and steel

${ }^{24}$ The following predictions apply to both cases 1 and 2 of the model with an AD duty. Equation (16) also includes the effect of a tariff. 
products that were investigated and found affirmative, hence receiving a final AD duty, and those products that were identified non-affirmative and did not receive a final AD duty. The other dimension is to estimate separate exchange rate pass-through coefficients for both the time period prior to the imposition of the final duty and the time period after its imposition. Our model predicts that, for affirmative products, the exchange rate pass-through coefficient undergoes a structural break at the time the final $\mathrm{AD}$ duty is imposed, but that the direction of the change is ambiguous. For the non-affirmatives, the model predicts that pass-through coefficient remains constant throughout our sample and equal to the coefficient for the affirmative products prior to the structural break.

Our second focus is to examine estimates of the coefficient on the AD duty variable -- $\ln \left(1+\mathrm{t}^{\mathrm{AD}}\right)$-permitting structural differences between the estimate for the period prior to the final duty and the estimate for the period after the final duty is imposed. Our primary prediction is that, because the final duty margin in our sample is eliminated over time for the affirmative products, the coefficient on the duty variable for the period after its final imposition may exceed unity and could approach two, implying passthrough of more than 100 percent of the duty.

\subsection{Data}

To test our model we examine data on U.S. imports of Canadian iron and steel products from 1989 through 1995. Examination of the Canadian case is appropriate for a number of reasons. As described in section 4, numerous Canadian iron and steel products were involved in U.S. AD steel cases filed in 1992. Canada was one of the largest import sources of iron and steel for the United States during this time period and was one of the source countries with large volumes of trade involved in the U.S. AD steel investigations and subsequent $\mathrm{AD}$ duties. The evidence from the duty determinations in administrative reviews after the case suggest that the involved Canadian firms altered behavior 
substantially to reduce the AD duty (see table 1). Furthermore, Canadian steel products were not subject to any U.S. VRAs before or during the time period of our data. Finally, we were able to gather much more detailed data to control for Canadian producer costs than for other source countries. As Knetter (1993) and Goldberg and Knetter (1997) point out, it is important to control as precisely as possible for cost shocks in empirical pass-through studies. These characteristics make the Canadian sample a natural one to test for altered behavior in the presence of the $\mathrm{AD}$ duty.

We sample monthly data for all 10-digit Canadian imports of iron and steel products covered under HTS codes 7201000000 up to 7220000000 . The U.S. AD investigation involved a substantial number of 10-digit HTS codes from HTS 7208000000 to 7220000000 . Identified by Federal Register notices connected to the case, a list of these subject codes is available from the authors upon request. Thus, our data cover two types of iron and steel products: those involved in the U.S. AD iron and steel cases that received an affirmative decision and $\mathrm{AD}$ duty, and those that either received a negative decision and no duty or were not involved in the cases. The presence of the latter type of products, the nonaffirmative products, allows us to identify the effect of the AD duty on the affirmative products.

Identification of $\mathrm{AD}$ effects is also facilitated by having monthly time-series data for each product beginning three years before the $\mathrm{AD}$ case was filed to almost two years after the final determination. As described in section 3, the U.S. AD steel investigations began in June 1992 and concluded in August 1993. The first administrative review occurred in August 1994 and examined transactions over the period of February 1993 through July 1994. These events occur in the middle of our 1989-1995 time series data. We begin the sample in January 1989 when data by HTS product codes first became available in the U. S. (rather than by the formerly-used TSUSA system). We end our sample in December 1995 because there were significant changes in the U.S. iron and steel HTS product codes that took effect in January of 1996, and we were not able to confidently concord these changes into the original HTS codes in our 
sample.

Our overall sample includes 345 10-digit HTS product codes, which vary substantially in terms of trade volumes, prices, and frequency of transactions. About two-thirds of the products do not have transactions for every month in our sample. However, over 70 percent of our observations are by products with transactions in at least three-quarters of the months. In our analysis below, we also estimate our model using only the 98 product codes that have complete time series. This subset allows us to address potential statistical concerns related to time-series properties of our data in a more explicit fashion.

Our dependent variable is the logarithm of the product's U.S. price inclusive of the AD duty and the tariff. Our U.S. price variable is constructed as monthly unit values for each of our products from official U.S. Customs data multiplied by one plus any applicable AD duty rate or ad valorem tariff rate. The data appendix describes construction of this variable and our other variables in more detail. We note that an ideal data set would have data by product and by firm to correspond with our firm-level theory. However, our product data encompasses activity by potentially numerous firms. The USDOC calculates $\mathrm{AD}$ duty rates by product and by firm, but also reports a trade-weighted average of the firm-specific $\mathrm{AD}$ duties by product which is called the "all other" duty, because it is applied to any new firm from the source country that enters and exports the subject product. We use this trade-weighted "all other" AD duty to construct our dependent variable. ${ }^{25}$

To obtain a first glance at the movement of the Canadian iron and steel prices during our sample period, figure 2 displays the trade-weighted average log of the unit value for affirmative and

${ }^{25}$ While the use of the "all other" AD duty and product level data to estimate firm-level passthrough is a concern, information in table 1 suggests that the firm, Stelco, Inc., was primarily responsible for the majority of U.S. imports of Canadian cut-to-length plate and corrosion-resistant steel. To see this, table 1 shows that the trade-weighted "all other" duty is very close to the firm-specific margin received by Stelco, Inc. 
nonaffirmative products in our sample. In figure 2 we also mark the beginning of the U.S. AD steel investigations (June 1992) and the final decision in the case (August 1993). Surprisingly, both these tradeweighted price series show significant changes after the case, with sharp increases in prices generally. One primary focus in this paper is the pass-through of exchange rate changes on prices before and after the conclusion of $\mathrm{AD}$ investigations. Figure 3 shows the movement of the U.S.dollar value of the Canadian dollar, end-of-month, for our sample period, and the beginning and end of the U.S. AD steel investigations. From 1989 to the beginning of 1992, the Canadian dollar was fairly stable, with a slight appreciation. This was followed by a significant depreciation of the Canadian dollar in 1992 and 1993, with a leveling off in 1994 and 1995. While the general trends in the exchange rate vary in the preinvestigation, investigation and post-investigation periods, each subperiod experiences both increases and decreases of the exchange rate.

Besides the logarithm of the exchange rate, other explanatory variables include the logarithms of the AD duty, tariff, Canadian producers' costs, the U.S. domestic substitute price, and Canadian and U.S. expenditures on steel. We note that, while the exchange rate and Canadian and U.S. expenditures on iron and steel variables vary only by time, the producer costs and U.S. domestic substitute prices vary by time and by product. The data appendix describes construction and sources of these variables. Table 2 displays descriptive statistics for our dependent variable and righthand-side variables for the full sample of 345 products, whereas table 3 displays these same statistics for the sample of 98 products with complete time series.

\section{Results}

\subsection{Initial estimates}

In this section, we present estimates of equation (16) and several variations using weighted least 
squares (WLS), where the weight is the customs value of the imported good. The reason for using WLS is because the volume and value of trade across the commodities is often very dissimilar. For some goods, there is modest or even zero trade for many months, and for other goods, there is substantial trade for all months. It thus seems inappropriate to weight each observation equally, since one would expect a greater variance in the residual for observations with modest trade relative to those with substantial trade. All WLS regressions include White's correction for heteroscedasticity (robust estimates), fixed-effect constants by product, and seasonal dummy variables. We also report estimates from alternative specifications including panel-specific autocorrelation and heteroscedasticity, dynamic or lagged effects, and tests of threat effects.

Table 4 summarizes pass-through estimates beginning with our full panel of 345 products from January 1989 to December 1995. Column (1) reports estimates of equation (16) for the full sample (17437 observations). All coefficients that have predicted signs are highly significant with the theoretically correct sign (only the theoretical signs on the two expenditure coefficients are ambiguous), supporting our basic pass-through specification. The coefficient on the exchange rate is 0.349 , indicating significant but incomplete pass-through, and we cannot reject the hypothesis that this coefficient is equal to the coefficient on the Canadian producer cost (0.251), supporting a common restriction imposed in this literature. The coefficient on the $\mathrm{AD}$ duty variable is significant at $0.818 .{ }^{26}$

Columns (2) and (3) in Table 4, respectively, report pass-through estimates of equation (16) for those products that received an affirmative decision and final AD duty (2608 observations) and estimates for the nonaffirmative products, which did not receive a final AD duty (14829 observations). Estimates

${ }^{26}$ If one drops the AD duty variable and re-estimates the column (1) specification (estimates are omitted for brevity), one obtains extremely similar estimates to those in column (1) that include the duty. One may infer from this that $\mathrm{AD}$ investigations and duties have no influence on exchange rate passthrough, but this inference is incorrect, as we demonstrate below. 
in columns (2) and (3) are very similar qualitatively to those in column (1), with the only major difference being a reduced statistical significance on most of the variables in column (2) (likely a result of the much smaller sample size). Given the strong similarity in the exchange rate pass-through coefficients in all three columns, as well as the similarity in the three AD duty coefficients, one would conclude that imposition of an $\mathrm{AD}$ duty has no effect on pass-through equations. In fact, this conclusion is spurious, resulting from imposing two invalid restrictions with the affirmative sample - a constant exchange rate coefficient and a constant $\mathrm{AD}$ duty coefficient before and after the period of final determination of the $\mathrm{AD}$ investigation.

Columns (4) and (5) in Table 4 relax these two restrictions for the affirmative and nonaffirmative products. In particular, the exchange rate coefficient, along with the AD duty coefficient, is permitted to differ in the period before the final determination (Jan. 1989 to August 1993) relative to the period after the final determination (September 1993 to Dec. 1995), noting that there was no duty, preliminary or final, prior to February 1993. Based on the affirmative sample, estimates in column (4) show that exchange rate pass-through prior to the final determination is not statistically different from zero, but becomes significant at 0.860 after the final determination. Furthermore, the coefficient on the AD duty variable increases from 0.876 to 1.626 for the period after final determination. Thus, column (4) supports a dramatic structural break with the affirmative products on both the exchange rate coefficient and the AD duty coefficient (structural change for each coefficient is significant at the 1 percent level), consistent with theoretical predictions. ${ }^{27}$ Importantly, unrestricted estimates based on the nonaffirmative sample lead to very different conclusions. The column (5) estimates do not support a structural break in

${ }^{27}$ We cannot reject the hypothesis that the pass-through of the tariff and the AD duty are equal in almost all specifications, despite our theory's prediction that the AD duty pass-through after the final determination should exceed the tariff. However, the estimate of pass-through of the tariff coefficient is often insignificant and sensitive to specification, unlike our estimated AD duty pass-through. 
exchange rate pass-through for nonaffirmative products. ${ }^{28}$ The two unrestricted exchange rate coefficients are not statistically different from one another (1 percent level) and are numerically similar to the column (4) estimate of exchange rate pass-through prior to the final determination -- findings also consistent with theoretical predictions. ${ }^{29}$

A potential limitation with estimates in Table 4 involves possible time series problems such as autocorrelation, a limitation that cannot be addressed with the full sample of 345 products because of missing observations associated with zero trade. We address this limitation by estimating the five specifications in Table 4 with generalized least squares for those 98 iron and steel products that have complete time series, and present these results in Tables 5 and 6 . To construct an appropriate benchmark, Table 5 repeats the Table 4 WLS, but for the sample of 98 products. These Table 5 WLS estimates support the major findings of Table 4. Table 5 estimates of the exchange rate coefficient in columns (1), (2), and (3) are very similar to one another (ranging between 0.273 and 0.314 ), as are the estimates of the $\mathrm{AD}$ coefficient (ranging between 0.736 and 0.954 ), yet, analogous to Table 4 , the bias in both these exchange rate and AD pass-through coefficients are revealed by the estimates in columns (4) and (5). In the column (4) estimates for the affirmative products, the exchange rate coefficient increases from zero to significantly positive (0.769) and the $\mathrm{AD}$ coefficient approximately doubles at the time of final determination; yet the column (5) estimate for the nonaffirmative products indicates no substantial

${ }^{28}$ The partial F-statistic comparing the restricted column (2) estimates to the unrestricted column (4) estimates is 8.18 , greater than the critical value $F(2,4)$ of 3.00 . This supports the structural break for the affirmative sample. The analogous F-statistic for column (3) versus column (5) is 0.27 , which is less than the critical value $F(1,4)$ of 3.84 , and therefore does not support a structural break for the nonaffirmative sample.

${ }^{29}$ The estimates in Table 4 do not support symmetry in pass-through between the exchange rate and the tariff, contrary to the finding in Feenstra (1989). It is clear from our model that this tariff symmetry is not necessarily predicted in the presence of the AD duty. The intuition is analogous to why the model predicts a change in exchange rate pass-through with a duty because the duty margin, the spread between the price of the export to the foreign country and the home price of the good, is endogenous. 
change in the exchange rate coefficient. ${ }^{30}$

Estimates in Table 6 repeat the benchmark estimates from Table 5 after GLS correction for panel specific autocorrelation and heteroscedasticity. The Table 6 GLS estimates support the major findings of both Tables 4 and 5. The exchange rate coefficients in columns (1), (2), and (3) are very similar to one another, as are the AD coefficients. However, for the column (4) estimates for the affirmative products, the exchange rate coefficient increases from zero to significantly positive and the AD coefficient approximately doubles at the time of the final determination; and for the column (5) estimates for the nonaffirmative products, there is no substantial change in the exchange rate coefficient.

\subsection{Dynamic considerations}

Tables 4, 5 and 6 ignore potential dynamic effects in our model. In particular, one may expect that, given monthly data, lagged values of the exchange rate may have an impact on the firms' pricing decisions, perhaps proxying for exchange rate expectations. ${ }^{31}$ If true, omission of lagged exchange rates suggests that our pass-through estimates above are biased downward. To examine this, we next create a one-half year moving average series of the logarithm of the exchange rate (contemporaneous plus the previous six monthly observations), and use this in place of the contemporaneous exchange rate specified above.

${ }^{30}$ The partial F-statistic for structural break the affirmative products in Table 5 is 16.47 , while partial F-statistic for structural break for the nonaffirmative products in Table 5 is 8.45 . Both support a structural break, but we note that for the nonaffirmative products the magnitude of the change in the exchange rate coefficient is small and in the opposite direction to the corresponding change in the affirmative products. Similiar "structural break" tests yield qualitatively identical results for all other estimates presented subsequently in the paper. Tests for structural break in exchange rate pass-through are always confirmed for estimates of the affirmative products, while tests for the nonaffirmative products either suggest no structural break or one that suggests a small downward shift after the final AD determination. Details are available from the authors upon request.

${ }^{31}$ Feenstra (1989) finds significant lagged effects in exchange rate pass-through, with the lagged response distributed over one year. 
Table 7 presents WLS estimates with this moving-average exchange rate variable for affirmative and nonaffirmative products for both our sample of 345 products (columns (1) and (2)) and the sample of 98 products (columns (3) through (6)), where the final two columns also use GLS methods to address panel specific autocorrelation and heterscedasticity The exchange rate pass-through elasticities increase substantially for the affirmative products relative to the static ones in Tables 4, 5 and 6, as one would expect, while curiously there is little change in the magnitudes of these elasticities for the nonaffirmative products. In addition, there is little qualitative (and in many cases, quantitative) changes in the other coefficients -- in particular, pass-through of $\mathrm{AD}$ duties is almost identical to the static specification and most coefficients on other variables are almost identical to previous estimates.

In sum, the structural break in exchange rate pass-through for the affirmative cases continues to hold with a dynamic specification, suggesting a large increase in pass-through of both the exchange rate and $\mathrm{AD}$ duty after the final determination. At the same time, the nonaffirmative products show no such structural break in the full sample. These results are robust to other lag lengths in our moving-average variables and to specifications that include the contemporaneous exchange rate and lagged exchange rates as separate regressors. ${ }^{32}$

A related issue is stationarity, a topic of concern with data that have a time series dimension. In general, the evidence suggests that this issue is likely not significant with our sample. First, 87 of the 98 price series that comprise our dependent variable in Tables 5, 6 and 7 reject the null hypothesis of a unit root using a Dickey-Fuller test at the 5 percent significance level. ${ }^{33}$ However, while the evidence suggests our dependent variable is stationary, our regressors, including logarithms of the exchange rate,

${ }^{32} \mathrm{We}$ also examined the inclusion of a lagged dependent variable as an alternative. The estimated coefficient on the lagged dependent variable was very small and statistically insignificant.

${ }^{33}$ This evidence for general stationarity of the dependent variable may not be surprising in light of the highly disaggregated nature of these price series. 
Canadian producer cost series, U.S. domestic price, U.S. expenditures on iron and steel, and Canadian expenditures on iron and steel, display mixed evidence with respect to stationarity. While Dickey-Fuller tests cannot reject a unit root for all series, a Phillips-Perron test rejects a unit root for the exchange rate, the U.S. domestic price, and eight of the nine Canadian producer cost series at the 1 percent significance level. We also conduct Dickey-Fuller tests on our residuals by estimating each of the 98 cross-sections separately and find that the tests reject a unit root in every case. If the non-stationarity properties of our regressors were serious, we would typically expect non-stationary residuals after regressing our stationary dependent variables on these regressors. Since this is not true, the evidence suggests our specification with data in levels is appropriate.

\subsection{Threat effects}

A number of papers have found empirical evidence suggesting that the threat of AD actions, including filings of $\mathrm{AD}$ petitions and preliminary determinations during $\mathrm{AD}$ investigations, can have effects that rival those observed when firms and products face actual AD duties. Staiger and Wolak (1994) and Krupp and Pollard (1996) show that AD petitions and preliminary determinations can have as large effects on prices and quantities as final determinations, depending on the characteristics of the market and firms involved in the case. Blonigen and Feenstra (1997) finds that the threat of U.S. AD protection has a stronger correlation with increases of Japanese foreign direct investment into the United States than measures of actual protection.

While we find no threat effects with our nonaffirmative estimates above, we examine threat effects in two additional ways. First, our nonaffirmative products include products that were not investigated as well as investigated products that received negative determinations. Both types of products ultimately face no AD duty, but firms might perceive the future likelihood of an AD investigation and affirmative decision for these two types of products differently and thus alter exchange 
rate pass-through accordingly. ${ }^{34}$ Our pooling of these two types of products may hide differences in exchange rate pass-through. The first two columns of Table 8 repeat for convenience our GLS estimates for the affirmative and nonaffirmative 98 products with complete time series, which were reported in columns (5) and (6) in Table 6. For comparison, columns (3) and (4) of Table 8, respectively, disaggregate our nonaffirmative estimates from column (2) into investigated-negative products and noninvestigated products. The exchange rate pass-through elasticities for the two categories of nonaffirmative products are extremely similar and remain unaffected by the final AD determination, which does not support threat effects based on this test.

A second method to detect threat effects is by potential changes in exchange rate pass-through when the products first received preliminary $\mathrm{AD}$ duties, rather than final duties. In the Canadian iron and steel AD cases, preliminary duties began in February of 1993, approximately 6 months before the final determination. Since the first administrative review by the USDOC included this period for their calculations of the revised dumping margins, the firms may have changed their exchange rate passthrough during this period before the final determination, particularly if they anticipated affirmative decisions. As an empirical test, we break the exchange rate pass-through elasticity estimates into three periods rather than two: 1) Before the preliminary determinations in February of 1993, 2) During the period between the preliminary and final determinations, and 3) After the final determination. Columns (5) and (6) of Table 8 report GLS estimates for affirmative and nonaffirmative products for this new specification, where the first row is exchange rate pass-through before the preliminary determination (as opposed to the final determination). Here again we find no evidence of threat effects. For both sets of

34 The reasoning is that if a firm thinks an AD investigation is likely in the near future and they wish to avoid $\mathrm{AD}$ duties, they will alter prices and pass-through currently because this may be the ultimate period of time used by the USDOC to determine the dumping margin. It is not clear whether a firm would consider a product that has already been investigated and received a negative determination more or less likely to receive an affirmative decision in the future. 
products, we find no difference between the exchange rate pass-through elasticity in the "before" or "during" period, but statistically significant differences for the affirmative products between the "after" period and both the "before" and "during" period. One potential explanation for this pattern is that it is unusual for the USDOC to use the period between the preliminary and final determinations for calculations of the dumping margin during the first administrative review (typically, they only use the period after the final determination), and the involved firms may not have anticipated that the USDOC would consider the period between the preliminary and final determinations in their first administrative review.

\section{Conclusion}

This paper finds that antidumping investigations and duties have substantial impacts on exchange rate and duty pass-through. With respect to exchange rate pass-through, we first present a model that indicates that structural breaks are likely to occur from $\mathrm{AD}$ duties because future administrative review duties are a function of the exchange rate. Our empirical results support this prediction by showing that, for our sample of U.S.-imported Canadian iron and steel products, exchange rate pass-through increased dramatically after products received final AD duties. We find no similar structural break for nonaffirmative products, regardless of whether they were investigated and received a negative determination or were never investigated.

We also find that pass-through of final AD duties was more than complete (greater than 100 percent) for our sample. This again is consistent with the way that future administrative reviews of AD duties are determined. In order to eliminate an AD duty in future reviews, a firm needs to pass-through the AD duty 200 percent assuming a fixed home-market price. Even with a variable home market price, pass-through of the duty to the export-market price is still likely to be greater than 100 percent. In fact, our estimates find $\mathrm{AD}$ duty pass-through to the export-market price to be around 160 percent. 
Consistent with previous literature, our results provide further evidence that the institutional structure surrounding $\mathrm{AD}$ investigations and duties can have many important (and often subtle) implications that transcend the simple ad valorem $\mathrm{AD}$ duties we observe. Furthermore, our analysis shows that ignoring the effects of $\mathrm{AD}$ investigations can lead to significantly biased estimates of passthrough elasticities for products that receive AD duties. Given the breadth of AD investigations and duties across U.S. manufacturing sectors, this critique may apply to many previous pass-through studies.

There are several extensions that follow naturally from our paper. First, we have not modeled or estimated the determination of the foreign firm's home market price of the product because the data were unavailable for our U.S.-Canadian sample. Joint estimation of both prices (home and export markets) would be useful to document effects of exchange rate changes on the home market price, as well as testing whether shifts in the home market price help establish the law of one price, despite partial passthrough of the exchange rate to the export market. Second, to evaluate the generality of our findings, it would be useful to examine the effect of $\mathrm{AD}$ investigations and duties on pass-through with firms from other countries and across other products. A promising sample for this extension might be Japan, since , like Canada, Japan is one of the largest exporters of iron and steel to the U.S. and faced significant duties, but unlike Canada, did not have the duties reviewed until a number of years after the final determination. 


\section{References}

Anderson, James E. "Domino Dumping I: Competitive Exporters," American Economic Review. Vol. 82 (1992): 65-83.

Anderson, James E. "Domino Dumping II: Anti-dumping," Journal of International Economics. Vol. 35 (1993): 133-150.

Baldwin, Richard. "Hysteresis in Import Prices: The Beachhead Effect," American Economic Review (September 1988): 773-785.

Blonigen, Bruce A. and Robert C. Feenstra." Protectionist Threats and Foreign Direct Investment," in Robert C. Feenstra (ed.), The Effects of U.S. Trade Protection and Promotion Policies. Chicago: University of Chicago Press (NBER), 1997, 55-80.

Boltuck, Richard D. “An Economic Analysis of Dumping,” Journal of World Trade Law. Vol. 21(1987): 45-54.

Feenstra, Robert C. "Symmetric Pass-Through of Tariffs and Exchange Rates Under Imperfect Competition: An Empirical Test," Journal of International Economics, Vol. 27(August 1989): 25-45.

Feenstra, Robert C., Joseph E. Gagnon, and Michael M. Knetter. "Market Share and Exchange Rate Pass-Through in World Automobile Trade," Journal of International Economics, Vol. 40(February 1996): 187-207.

Feinberg, Robert M. “Exchange Rates and 'Unfair Trade,"” Review of Economics and Statistics, Vol. 71(November 1989): 704-07.

Froot, Kenneth A. and Paul D. Klemperer, "Exchange Rate Pass-Through When Market Share Matters," American Economic Review, Vol. 79(September 1989): 637-654.

Gallaway, Michael P., Bruce A. Blonigen and Joseph E. Flynn. "Welfare Costs of the U.S. Antidumping and Countervailing Duty Laws," Journal of International Economics, forthcoming.

Goldberg, Penelopi Koujianou and Michael M. Knetter. Goods Prices and Exchange Rates: What Have We Learned?" Journal of Economic Literature, Vol. 35(September 1997): 1244-72.

Gron, Anne and Deborah L. Swenson. "Incomplete Exchange-Rate Pass-Through and Imperfect Competition: The Effect of Local Production," American Economic Review Papers and Proceedings, Vol. 86(May 1996): 71-76.

Harrison, Ann. "Imperfect Explanations for Imperfect Pass-Through: Market Power and Exchange Rates in the US Steel Industry," Mimeo, July 1992.

Knetter, Michael M. "International Comparison of Pricing-to-Market Behavior," American Economic Review, Vol. 83(June 1993): 473-86. 
Knetter, Michael M. "Is Export Price Adjustment Asymmetric?: Evaluating the Market Share and Marketing Bottlenecks Hypotheses," Journal of International Money and Finance, Vol. 13(February 1994): 55-70.

Krupp, Corinne M. and Patricia S. Pollard. "Market Responses to Antidumping Laws: Some Evidence from the U.S. Chemical Industry," Canadian Journal of Economics. Vol. 29(1996): 199-227.

Prusa, Thomas J. "The Trade Effects of U.S. Antidumping Actions," in Robert C. Feenstra (ed.), The Effects of U.S. Trade Protection and Promotion Policies. Chicago: University of Chicago Press (NBER), 1997, 191-212.

Rosendorff, B. Peter. "Voluntary Export Restraints, Antidumping Procedure, and Domestic Politics," American Economic Review. Vol. 86(June 1996): 544-61.

Staiger, Robert W. and Frank A. Wolak. "Measuring Industry-Specific Protection: Antidumping in the United States," Brookings Papers on Economic Activity: Microeconomics, 1994: 51-118.

U.S. International Trade Commission. The Year in Trade: Operation of the Trade Agreements Program, 45 ${ }^{\text {th }}$ Report. USITC Publication 2769. Washington, DC: U.S. International Trade Commission, 1994.

Yang, Jiawen. "Exchange Rate Pass-Through in U.S. Manufacturing Industries," Review of Economics and Statistics, Vol. 79(February 1996): 95-104. 
Figure 1: Timeline of U.S. Antidumping Investigations of Steel Products, 1992-1993.

\begin{tabular}{|c|c|c|c|c|}
\hline Petition filed & $\begin{array}{l}\text { Negative USITC } \\
\text { preliminary } \\
\text { determination } \\
\text { for select cases }\end{array}$ & $\begin{array}{l}\text { Preliminary } \\
\text { USDOC } \\
\text { determination }\end{array}$ & $\begin{array}{l}\text { Final USDOC } \\
\text { determination }\end{array}$ & $\begin{array}{l}\text { Final USITC } \\
\text { determination } \\
\text { and } \\
\text { antidumping } \\
\text { orders }\end{array}$ \\
\hline June 8 & August 21 & February 4 & July 9 & August $18 / 19$ \\
\hline 1992 & 1992 & 1993 & 1993 & 1993 \\
\hline
\end{tabular}

Figure 2: Log of trade-weighted prices for affirmative and nonaffirmative

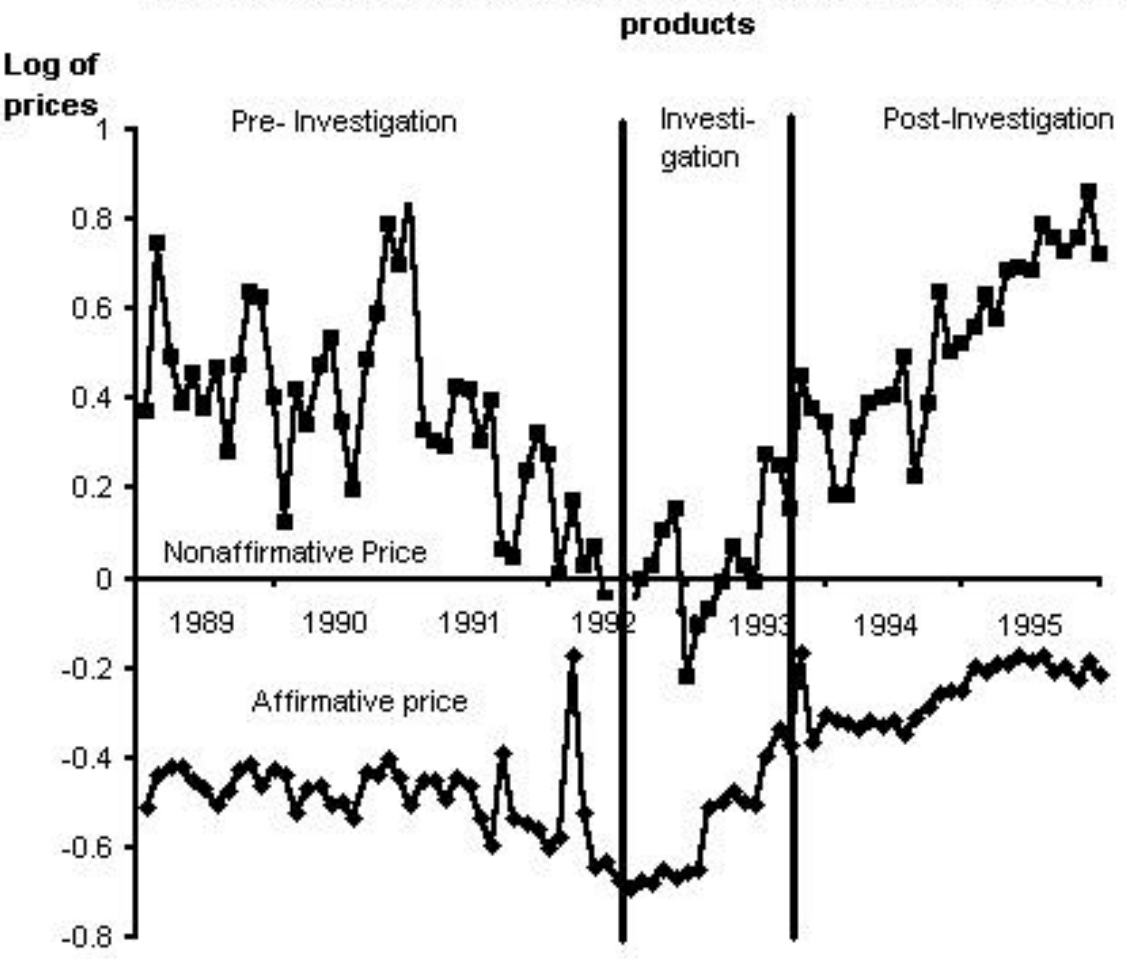


Figure 3: Exchange rate (U.S. dollars per Canadian dollar)

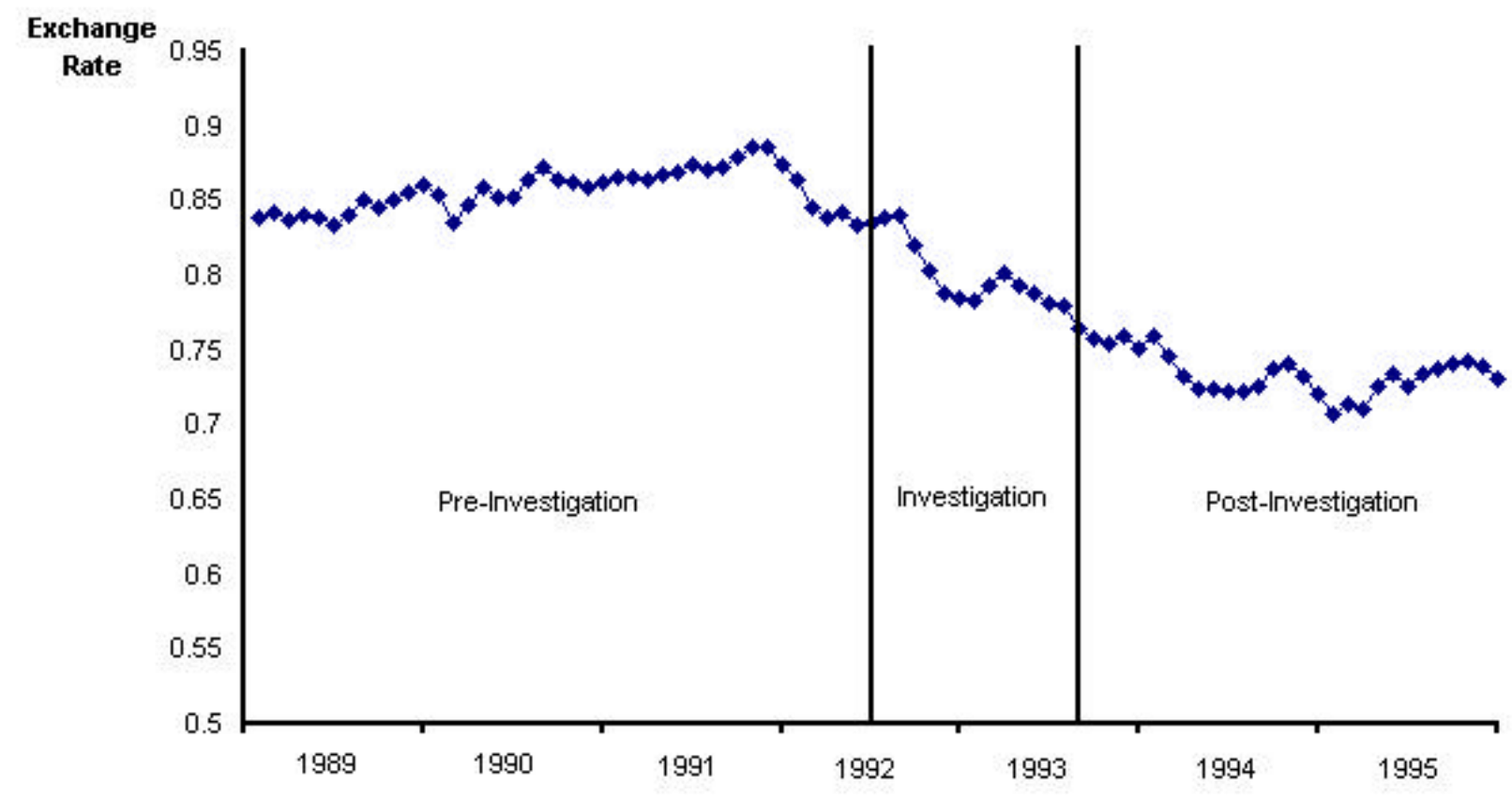


Table 1: Progression of AD duties over time from administrative review process in the1992-93 U.S. steel cases involving Canada.

\begin{tabular}{|c|c|c|c|c|c|c|}
\hline \multirow[t]{2}{*}{ Products } & \multicolumn{2}{|c|}{ Investigation } & \multicolumn{2}{|c|}{$\begin{array}{c}\text { First Review } \\
\text { Period of Invest.: } \\
\text { 2/4/93 - 7/31/94 }\end{array}$} & \multicolumn{2}{|c|}{$\begin{array}{l}\text { Second Review } \\
\text { Period of Invest.: } \\
8 / 1 / 94 \text { - 7/31/95 }\end{array}$} \\
\hline & Duty ${ }^{a}$ & Method ${ }^{b}$ & Duty $^{a}$ & Method ${ }^{b}$ & Duty ${ }^{a}$ & Method ${ }^{b}$ \\
\hline$\underline{\text { Cut-to-length Plate }}$ & & & & & & \\
\hline IPSCO & 1.47 & HM & 1.65 & $\mathrm{HM} / \mathrm{CV}$ & $0.59^{d}$ & HM \\
\hline Stelco, Inc. & 68.70 & HM & 0.19 & $\mathrm{HM} / \mathrm{CV}$ & 0.55 & HM \\
\hline Continuous Colour Cast & 61.95 & All Oth. & 1.96 & $\mathrm{HM} / \mathrm{CV}$ & $1.31^{\mathrm{d}}$ & $\mathrm{HM}$ \\
\hline Corrosion-resistant & & & & & & \\
\hline Dofasco & $1.69^{c}$ & HM & & & & \\
\hline Stelco, Inc. & 28.27 & HM & 0.92 & $\mathrm{HM} / \mathrm{CV}$ & 0.00 & HM \\
\hline Algoma Steel Inc. & 22.29 & All Oth. & 1.82 & $\mathrm{HM} / \mathrm{CV}$ & 0.37 & $\mathrm{HM}$ \\
\hline Manitoba Rolling Mills & 22.29 & All Oth. & 0.02 & $\mathrm{HM} / \mathrm{CV}$ & WD & \\
\hline
\end{tabular}

${ }^{a}$ In percent. WD indicates the firm withdrew its request for a review.

b Indicates the method used to determine fair market value by USDOC. "HM" indicates they used home market transactions, "HM/CV" indicates USDOC used home market transactions, but also ruled out some as "below cost" using a constructed value method, and "All oth." indicates that a dumping margin was not calculated for the specific firm at the time of the investigation and thus, the "all other" margin (a trade-weighted margin of the firms for which a dumping margin was calculated) was applied.

${ }^{\mathrm{c}}$ Initial duty, calculated by USDOC, was 10.89 , but ministerial errors led to correction and this lower duty as of March 1994.

${ }^{\mathrm{d}}$ Duty that was amended subsequent to final determination due to ministerial errors. In both cases the correction was very small. 
Table 2: Descriptive statistics of variables for sample of all 345 products.

\begin{tabular}{lcccc}
\hline Variable & Mean & $\begin{array}{c}\text { Standard } \\
\text { Deviation }\end{array}$ & Min & Max \\
\hline Logarithm of U.S. price. & 0.103 & 1.677 & -2.948 & 8.977 \\
Logarithm of U.S. dollar price of Canadian dollar. & -0.220 & 0.072 & -0.346 & -0.121 \\
Logarithm of (1+ AD duty). & 0.015 & 0.062 & 0.000 & 0.523 \\
Logarithm of (1+ tariff) & 0.025 & 0.017 & 0.000 & 0.096 \\
Logarithm of Canadian producer costs. & 4.671 & 0.086 & 4.468 & 4.984 \\
Logarithm of U.S. domestic substitute price. & 4.728 & 0.075 & 4.556 & 4.885 \\
Logarithm of U.S. expenditures on steel. & 8.674 & 0.116 & 8.451 & 8.940 \\
Logarithm of Canadian expenditures on steel. & 6.679 & 0.206 & 6.300 & 7.112 \\
\hline
\end{tabular}

Notes: The full sample has 17,449 observations. See data appendix for sources and construction of variables.

Table 3: Descriptive statistics of variables for sample of 98 products with complete time series.

\begin{tabular}{lcccc}
\hline Variable & Mean & $\begin{array}{c}\text { Standard } \\
\text { Deviation }\end{array}$ & Min & Max \\
\hline Logarithm of U.S. price. & 0.081 & 1.920 & -1.902 & 7.470 \\
Logarithm of U.S. dollar price of Canadian dollar. & -0.219 & 0.072 & -0.346 & -0.121 \\
Logarithm of (1+ AD duty). & 0.014 & 0.061 & 0.000 & 0.523 \\
Logarithm of (1+ tariff) & 0.022 & 0.016 & 0.000 & 0.065 \\
Logarithm of Canadian producer costs. & 4.667 & 0.085 & 4.468 & 4.874 \\
Logarithm of U.S. domestic substitute price. & 4.727 & 0.077 & 4.556 & 4.885 \\
Logarithm of U.S. expenditures on steel. & 8.671 & 0.115 & 8.451 & 8.940 \\
Logarithm of Canadian expenditures on steel. & 6.674 & 0.205 & 6.300 & 7.112 \\
\hline
\end{tabular}

Notes: The sample of 98 products with complete time series has 8,232 observations. See data appendix for sources and construction of variables. 
Table 4: Pass-through estimates for U.S.-imported Canadian iron and steel products, 1989-1995, using weighted ordinary least squares and fixed effects - sample of 345 products.

\begin{tabular}{|c|c|c|c|c|c|}
\hline & $\begin{array}{c}\text { Full } \\
\text { Sample }\end{array}$ & $\begin{array}{l}\text { Affirm } \\
\text { Sample }\end{array}$ & $\begin{array}{l}\text { Nonaffirm } \\
\text { Sample }\end{array}$ & $\begin{array}{l}\text { Affirm } \\
\text { Sample }\end{array}$ & $\begin{array}{l}\text { Nonaffirm } \\
\text { Sample }\end{array}$ \\
\hline Regressors & (1) & (2) & (3) & (4) & $(5)$ \\
\hline U.S. dollar price of Canadian dollar & $\begin{array}{l}0.349 * * \\
(0.078)\end{array}$ & $\begin{array}{c}0.407 \\
(0.283)\end{array}$ & $\begin{array}{l}0.381 * * \\
(0.083)\end{array}$ & & \\
\hline $\begin{array}{l}\text { U.S. dollar price of Canadian dollar } \\
* \text { Period before final determination }\end{array}$ & & & & $\begin{array}{c}0.245 \\
(0.338)\end{array}$ & $\begin{array}{l}0.406 * * \\
(0.079)\end{array}$ \\
\hline $\begin{array}{l}\text { U.S. dollar price of Canadian dollar } \\
* \text { Period after final determination }\end{array}$ & & & & $\begin{array}{l}0.860^{* *} \\
(0.316)\end{array}$ & $\begin{array}{l}0.385^{* *} \\
(0.080)\end{array}$ \\
\hline $1+\mathrm{AD}$ duty & $\begin{array}{l}0.818 * * \\
(0.051)\end{array}$ & $\begin{array}{l}1.006^{* *} \\
(0.068)\end{array}$ & $\begin{array}{l}0.975^{* *} \\
(0.081)\end{array}$ & & \\
\hline $\begin{array}{l}(1+\mathrm{AD} \text { duty }) * \text { Period during } \\
\text { investigation }\end{array}$ & & & & $\begin{array}{l}0.876 * * \\
(0.071)\end{array}$ & $\begin{array}{l}1.053 * * \\
(0.085)\end{array}$ \\
\hline $\begin{array}{l}(1+\mathrm{AD} \text { duty }) * \text { Period after final } \\
\text { determination }\end{array}$ & & & & $\begin{array}{l}1.626 * * \\
(0.184)\end{array}$ & \\
\hline $1+$ tariff & $\begin{array}{l}1.384 * * \\
(0.400)\end{array}$ & $\begin{array}{l}2.337 * * \\
(0.900)\end{array}$ & $\begin{array}{l}1.176^{* *} \\
(0.449)\end{array}$ & $\begin{array}{r}1.563 \\
(0.803)\end{array}$ & $\begin{array}{c}1.185^{*} \\
(0.467)\end{array}$ \\
\hline Canadian producer costs & $\begin{array}{l}0.251 * * \\
(0.057)\end{array}$ & $\begin{array}{c}0.294 \\
(0.215)\end{array}$ & $\begin{array}{l}0.274 * * \\
(0.059)\end{array}$ & $\begin{array}{c}0.376 \\
(0.228)\end{array}$ & $\begin{array}{l}0.272 * * \\
(0.058)\end{array}$ \\
\hline U.S. domestic substitute price & $\begin{array}{l}0.628 * * \\
(0.101)\end{array}$ & $\begin{array}{c}0.352 \\
(0.416)\end{array}$ & $\begin{array}{l}0.595 * * \\
(0.099)\end{array}$ & $\begin{array}{c}0.246 \\
(0.374)\end{array}$ & $\begin{array}{l}0.583 * * \\
(0.103)\end{array}$ \\
\hline U.S. expenditures on steel & $\begin{array}{c}-0.155^{* *} \\
(0.059)\end{array}$ & $\begin{array}{r}-0.119 \\
(0.120)\end{array}$ & $\begin{array}{c}-0.154^{*} \\
(0.068)\end{array}$ & $\begin{array}{r}-0.060 \\
(0.109)\end{array}$ & $\begin{array}{r}-0.170 * \\
(0.072)\end{array}$ \\
\hline Canadian expenditures on steel & $\begin{array}{l}0.219 * * \\
(0.032)\end{array}$ & $\begin{array}{l}0.151^{* *} \\
(0.058)\end{array}$ & $\begin{array}{l}0.234 * * \\
(0.036)\end{array}$ & $\begin{array}{l}0.154 * * \\
(0.056)\end{array}$ & $\begin{array}{l}0.239 * * \\
(0.036)\end{array}$ \\
\hline R-squared & 0.99 & 0.82 & 0.99 & 0.82 & 0.99 \\
\hline F Test & $95.37 * *$ & $48.77 * *$ & $62.71 * *$ & $46.68 * *$ & $61.89 * *$ \\
\hline Sample Size & 17437 & 2608 & 14829 & 2608 & 14829 \\
\hline
\end{tabular}


Table 5: Pass-through estimates for U.S.-imported Canadian iron and steel products, 1989-1995, using weighted ordinary least squares and fixed effects - sample of 98 products with complete time series.

\begin{tabular}{|c|c|c|c|c|c|}
\hline & $\begin{array}{c}\text { Full } \\
\text { Sample }\end{array}$ & $\begin{array}{l}\text { Affirm } \\
\text { Sample }\end{array}$ & $\begin{array}{l}\text { Nonaffirm } \\
\text { Sample }\end{array}$ & $\begin{array}{l}\text { Affirm } \\
\text { Sample }\end{array}$ & $\begin{array}{l}\text { Nonaffirm } \\
\text { Sample }\end{array}$ \\
\hline Regressors & (1) & (2) & (3) & (4) & (5) \\
\hline U.S. dollar price of Canadian dollar & $\begin{array}{l}0.273 * * \\
(0.086)\end{array}$ & $\begin{array}{c}0.292 \\
(0.289)\end{array}$ & $\begin{array}{l}0.314 * * \\
(0.093)\end{array}$ & & \\
\hline $\begin{array}{l}\text { U.S. dollar price of Canadian dollar } \\
* \text { Period before final determination }\end{array}$ & & & & $\begin{array}{c}0.113 \\
(0.357)\end{array}$ & $\begin{array}{l}0.473^{* *} \\
(0.086)\end{array}$ \\
\hline $\begin{array}{l}\text { U.S. dollar price of Canadian dollar } \\
* \text { Period after final determination }\end{array}$ & & & & $\begin{array}{c}0.769^{*} \\
(0.301)\end{array}$ & $\begin{array}{l}0.348^{* *} \\
(0.088)\end{array}$ \\
\hline $1+\mathrm{AD}$ duty & $\begin{array}{l}0.736 * * \\
(0.052)\end{array}$ & $\begin{array}{l}0.954 * * \\
(0.060)\end{array}$ & $\begin{array}{l}0.896 * * \\
(0.089)\end{array}$ & & \\
\hline $\begin{array}{l}(1+\mathrm{AD} \text { duty }) * \text { Period during } \\
\text { investigation }\end{array}$ & & & & $\begin{array}{l}0.858 * * \\
(0.075)\end{array}$ & $\begin{array}{l}1.089 * * \\
(0.093)\end{array}$ \\
\hline $\begin{array}{l}(1+\mathrm{AD} \text { duty }) * \text { Period after final } \\
\text { determination }\end{array}$ & & & & $\begin{array}{l}1.583 * * \\
(0.111)\end{array}$ & \\
\hline $1+$ tariff & $\begin{array}{c}0.986^{*} \\
(0.405)\end{array}$ & $\begin{array}{l}2.823 * * \\
(0.897)\end{array}$ & $\begin{array}{c}0.518 \\
(0.446)\end{array}$ & $\begin{array}{c}1.890^{*} \\
(0.775)\end{array}$ & $\begin{array}{c}0.663 \\
(0.471)\end{array}$ \\
\hline Canadian producer costs & $\begin{array}{l}0.205^{* *} \\
(0.066)\end{array}$ & $\begin{array}{c}0.058 \\
(0.243)\end{array}$ & $\begin{array}{l}0.256^{* *} \\
(0.063)\end{array}$ & $\begin{array}{c}0.168 \\
(0.263)\end{array}$ & $\begin{array}{l}0.230 * * \\
(0.061)\end{array}$ \\
\hline U.S. domestic substitute price & $\begin{array}{l}0.433 * * \\
(0.117)\end{array}$ & $\begin{array}{c}0.655 \\
(0.482)\end{array}$ & $\begin{array}{l}0.351 * * \\
(0.112)\end{array}$ & $\begin{array}{c}0.575 \\
(0.443)\end{array}$ & $\begin{array}{l}0.318 * * \\
(0.116)\end{array}$ \\
\hline U.S. expenditures on steel & $\begin{array}{l}-0.098 \\
(0.067)\end{array}$ & $\begin{array}{r}-0.072 \\
(0.131)\end{array}$ & $\begin{array}{r}-0.096 \\
(0.078)\end{array}$ & $\begin{array}{c}-0.000 \\
(0.120)\end{array}$ & $\begin{array}{r}-0.162 * \\
(0.082)\end{array}$ \\
\hline Canadian expenditures on steel & $\begin{array}{l}0.227 * * \\
(0.035)\end{array}$ & $\begin{array}{l}0.167 * * \\
(0.061)\end{array}$ & $\begin{array}{l}0.238 * * \\
(0.041)\end{array}$ & $\begin{array}{l}0.160 * * \\
(0.061)\end{array}$ & $\begin{array}{l}0.260 * * \\
(0.041)\end{array}$ \\
\hline R-squared & 0.99 & 0.83 & 0.99 & 0.83 & 0.99 \\
\hline F Test & $85.59 * *$ & $53.89 * *$ & $53.79 * *$ & $70.48 * *$ & $53.29 * *$ \\
\hline Sample Size & 8232 & 1008 & 7224 & 1008 & 7224 \\
\hline
\end{tabular}

NOTES: The dependent variable is the U.S. price (inclusive of the duties and tariffs) of the Canadian imported steel product. All variables are in logarithms. Robust standard errors are in parentheses, with ** and * denoting statistical significance (two-tailed test) at the 1 and 5 percent levels, respectively. 
Table 6: Pass-through estimates for U.S.-imported Canadian iron and steel products, 1989-1995, using weighted generalized least squares and fixed effects - sample of 98 products with complete time series.

\begin{tabular}{|c|c|c|c|c|c|}
\hline & $\begin{array}{l}\text { Full } \\
\text { Sample }\end{array}$ & $\begin{array}{l}\text { Affirm } \\
\text { Sample }\end{array}$ & $\begin{array}{l}\text { Nonaffirm } \\
\text { Sample }\end{array}$ & $\begin{array}{l}\text { Affirm } \\
\text { Sample }\end{array}$ & $\begin{array}{l}\text { Nonaffirm } \\
\text { Sample }\end{array}$ \\
\hline Regressors & (1) & (2) & (3) & (4) & (5) \\
\hline U.S. dollar price of Canadian dollar & $\begin{array}{l}0.080 * \\
(0.033)\end{array}$ & $\begin{array}{c}0.109 \\
(0.152)\end{array}$ & $\begin{array}{l}0.109 * * \\
(0.033)\end{array}$ & & \\
\hline $\begin{array}{l}\text { U.S. dollar price of Canadian dollar } \\
* \text { Period before final determination }\end{array}$ & & & & $\begin{array}{r}-0.111 \\
(0.161)\end{array}$ & $\begin{array}{l}0.183 * * \\
(0.039)\end{array}$ \\
\hline $\begin{array}{l}\text { U.S. dollar price of Canadian dollar } \\
* \text { Period after final determination }\end{array}$ & & & & $\begin{array}{l}0.550 * * \\
(0.190)\end{array}$ & $\begin{array}{l}0.121 * * \\
(0.033)\end{array}$ \\
\hline $1+\mathrm{AD}$ duty & $\begin{array}{l}0.872 * * \\
(0.027)\end{array}$ & $\begin{array}{l}0.909 * * \\
(0.063)\end{array}$ & $\begin{array}{l}0.976 * * \\
(0.067)\end{array}$ & & \\
\hline $\begin{array}{l}(1+\mathrm{AD} \text { duty }) * \text { Period during } \\
\text { investigation }\end{array}$ & & & & $\begin{array}{l}0.797 * * \\
(0.058)\end{array}$ & $\begin{array}{l}1.036 * * \\
(0.069)\end{array}$ \\
\hline $\begin{array}{l}(1+\mathrm{AD} \text { duty }) * \text { Period after final } \\
\text { determination }\end{array}$ & & & & $\begin{array}{l}1.503 * * \\
(0.157)\end{array}$ & \\
\hline $1+$ tariff & $\begin{array}{l}2.743 * * \\
(0.262)\end{array}$ & $\begin{array}{l}3.055^{* *} \\
(0.778)\end{array}$ & $\begin{array}{l}2.448 * * \\
(0.282)\end{array}$ & $\begin{array}{l}2.229 * * \\
(0.748)\end{array}$ & $\begin{array}{l}2.668 * * \\
(0.284)\end{array}$ \\
\hline Canadian producer costs & $\begin{array}{l}0.278 * * \\
(0.032)\end{array}$ & $\begin{array}{c}0.144 \\
(0.103)\end{array}$ & $\begin{array}{l}0.336 * * \\
(0.034)\end{array}$ & $\begin{array}{l}0.300 * * \\
(0.101)\end{array}$ & $\begin{array}{l}0.320 * * \\
(0.035)\end{array}$ \\
\hline U.S. domestic substitute price & $\begin{array}{l}0.450 * * \\
(0.053)\end{array}$ & $\begin{array}{c}0.585^{*} \\
(0.246)\end{array}$ & $\begin{array}{l}0.378 * * \\
(0.054)\end{array}$ & $\begin{array}{c}0.386 \\
(0.237)\end{array}$ & $\begin{array}{l}0.357 * * \\
(0.053)\end{array}$ \\
\hline U.S. expenditures on steel & $\begin{array}{l}0.007 \\
(0.020)\end{array}$ & $\begin{array}{c}-0.091 \\
(0.073)\end{array}$ & $\begin{array}{c}0.034 * \\
(0.020)\end{array}$ & $\begin{array}{r}-0.098 \\
(0.079)\end{array}$ & $\begin{array}{l}0.021 \\
(0.020)\end{array}$ \\
\hline Canadian expenditures on steel & $\begin{array}{l}0.050 * * \\
(0.010)\end{array}$ & $\begin{array}{c}0.076 \\
(0.040)\end{array}$ & $\begin{array}{l}0.049 * * \\
(0.010)\end{array}$ & $\begin{array}{l}0.126^{* *} \\
(0.043)\end{array}$ & $\begin{array}{l}0.056 * * \\
(0.010)\end{array}$ \\
\hline Wald $\times^{2}$ statistic & $1339650 * *$ & $3788.58 * *$ & $\begin{array}{r}1437391 \\
* *\end{array}$ & $\begin{array}{r}4963.40 \\
* *\end{array}$ & $\begin{array}{r}1456510 \\
* *\end{array}$ \\
\hline Sample Size & 8232 & 1008 & 7224 & 1008 & 7224 \\
\hline
\end{tabular}


Table 7: Pass-through estimates for U.S.-imported Canadian iron and steel products, 1989-1995, using weighted least squares and fixed effects - using moving average lags of exchange rate terms.

\begin{tabular}{|c|c|c|c|c|c|c|}
\hline \multirow[b]{2}{*}{ Regressors } & \multicolumn{2}{|c|}{$\begin{array}{l}\text { Sample of } 345 \\
\text { products, } \\
\text { weighted OLS }\end{array}$} & \multicolumn{2}{|c|}{$\begin{array}{l}\text { Sample of } 98 \\
\text { products, } \\
\text { weighted OLS }\end{array}$} & \multicolumn{2}{|c|}{$\begin{array}{l}\text { Sample of } 98 \\
\text { products, } \\
\text { weighted GLS }\end{array}$} \\
\hline & $\begin{array}{l}\text { Affirm } \\
\text { (1) }\end{array}$ & $\begin{array}{l}\text { Nonaff } \\
\text { (2) }\end{array}$ & $\begin{array}{l}\text { Affirm } \\
\text { (3) }\end{array}$ & $\begin{array}{l}\text { Nonaff } \\
\text { (4) }\end{array}$ & $\begin{array}{l}\text { Affirm } \\
(5)\end{array}$ & $\begin{array}{l}\text { Nonaff } \\
\text { (6) }\end{array}$ \\
\hline $\begin{array}{l}\text { Moving-average of U.S. } \\
\text { dollar price of Canadian } \\
\text { dollar * Period before final } \\
\text { determination }\end{array}$ & $\begin{array}{c}0.736 \\
(0.691)\end{array}$ & $\begin{array}{l}0.418 * * \\
(0.095)\end{array}$ & $\begin{array}{c}0.619 \\
(0.776)\end{array}$ & $\begin{array}{l}0.473 * * \\
(0.103)\end{array}$ & $\begin{array}{c}0.111 \\
(0.209)\end{array}$ & $\begin{array}{l}0.175 * * \\
(0.052)\end{array}$ \\
\hline $\begin{array}{l}\text { Moving-average of U.S. } \\
\text { dollar price of Canadian } \\
\text { dollar * Period after final } \\
\text { determination }\end{array}$ & $\begin{array}{c}1.315^{*} \\
(0.598)\end{array}$ & $\begin{array}{l}0.418^{* *} \\
(0.097)\end{array}$ & $\begin{array}{c}1.230 \\
(0.653)\end{array}$ & $\begin{array}{l}0.372 * * \\
(0.108)\end{array}$ & $\begin{array}{l}0.769 * * \\
(0.248)\end{array}$ & $\begin{array}{l}0.119 * * \\
(0.043)\end{array}$ \\
\hline $\begin{array}{l}(1+\mathrm{AD} \text { duty }) * \text { Period } \\
\text { during investigation }\end{array}$ & $\begin{array}{l}0.932 * * \\
(0.105)\end{array}$ & $\begin{array}{l}1.051 * * \\
(0.084)\end{array}$ & $\begin{array}{l}0.911 * * \\
(0.115)\end{array}$ & $\begin{array}{l}1.082 * * \\
(0.091)\end{array}$ & $\begin{array}{l}0.801 * * \\
(0.064)\end{array}$ & $\begin{array}{l}1.033 * * \\
(0.070)\end{array}$ \\
\hline $\begin{array}{l}(1+\mathrm{AD} \text { duty }) * \text { Period } \\
\text { after final determination }\end{array}$ & $\begin{array}{l}1.596 * * \\
(0.198)\end{array}$ & & $\begin{array}{l}1.543^{* *} \\
(0.110)\end{array}$ & & $\begin{array}{l}1.467 * * \\
(0.166)\end{array}$ & \\
\hline $1+$ tariff & $\begin{array}{c}0.048 \\
(1.422)\end{array}$ & $\begin{array}{r}1.213 * \\
(0.496)\end{array}$ & $\begin{array}{c}0.258 \\
(1.584)\end{array}$ & $\begin{array}{c}0.761 \\
(0.512)\end{array}$ & $\begin{array}{c}1.114 \\
(0.874)\end{array}$ & $\begin{array}{l}2.734 * * \\
(0.292)\end{array}$ \\
\hline Canadian producer costs & $\begin{array}{l}0.401 * \\
(0.197)\end{array}$ & $\begin{array}{l}0.312 * * \\
(0.056)\end{array}$ & $\begin{array}{c}0.181 \\
(0.219)\end{array}$ & $\begin{array}{l}0.279 * * \\
(0.058)\end{array}$ & $\begin{array}{l}0.268 * * \\
(0.102)\end{array}$ & $\begin{array}{l}0.342 * * \\
(0.035)\end{array}$ \\
\hline $\begin{array}{l}\text { U.S. domestic substitute } \\
\text { price }\end{array}$ & $\begin{array}{c}0.296 \\
(0.312)\end{array}$ & $\begin{array}{l}0.595^{* *} \\
(0.104)\end{array}$ & $\begin{array}{c}0.603 \\
(0.349)\end{array}$ & $\begin{array}{l}0.323^{* *} \\
(0.116)\end{array}$ & $\begin{array}{l}0.529 * \\
(0.243)\end{array}$ & $\begin{array}{l}0.352 * * \\
(0.053)\end{array}$ \\
\hline U.S. expenditures on steel. & $\begin{array}{l}-0.097 \\
(0.105)\end{array}$ & $\begin{array}{l}-0.186 * * \\
(0.070)\end{array}$ & $\begin{array}{l}-0.032 \\
(0.115)\end{array}$ & $\begin{array}{c}-0.177 * \\
(0.079)\end{array}$ & $\begin{array}{l}-0.110 \\
(0.079)\end{array}$ & $\begin{array}{c}0.018 \\
(0.020)\end{array}$ \\
\hline $\begin{array}{l}\text { Canadian expenditures on } \\
\text { steel. }\end{array}$ & $\begin{array}{l}0.245^{* *} \\
(0.086)\end{array}$ & $\begin{array}{l}0.254 * * \\
(0.036)\end{array}$ & $\begin{array}{l}0.255^{* *} \\
(0.095)\end{array}$ & $\begin{array}{l}0.273^{* *} \\
(0.040)\end{array}$ & $\begin{array}{l}0.157 * * \\
(0.045)\end{array}$ & $\begin{array}{l}0.056^{* *} \\
(0.011)\end{array}$ \\
\hline R-squared & 0.82 & 0.99 & 0.83 & 0.99 & & \\
\hline $\begin{array}{l}F \text { Test (Wald } \times^{2} \text { statistic } \\
\text { for GLS) }\end{array}$ & $46.19 * *$ & $61.84 * *$ & $59.99 * *$ & $53.42 * *$ & $\begin{array}{r}4933.55 \\
* *\end{array}$ & $\begin{array}{r}1495306 \\
* *\end{array}$ \\
\hline Sample Size & 2608 & 14829 & 1008 & 7224 & 1008 & 7224 \\
\hline
\end{tabular}

NOTES: The dependent variable is the U.S. price (inclusive of the duties and tariffs) of the Canadian imported steel product. All variables are in logarithms. Robust standard errors are in parentheses, with ** and $*$ denoting statistical significance (two-tailed test) at the 1 and 5 percent levels, respectively. 
Table 8: Pass-through estimates for U.S.-imported Canadian iron and steel products, 1989-1995, using weighted generalized least squares and fixed effects - estimates of threat effects.

\begin{tabular}{|c|c|c|c|c|c|c|}
\hline \multirow[b]{2}{*}{ Regressors } & \multicolumn{2}{|c|}{$\begin{array}{l}\text { Sample of } 98 \\
\text { products, } \\
\text { weighted GLS }\end{array}$} & \multicolumn{2}{|c|}{$\begin{array}{l}\text { Sample of } 98 \\
\text { products, } \\
\text { weighted GLS }\end{array}$} & \multicolumn{2}{|c|}{$\begin{array}{l}\text { Sample of } 98 \\
\text { products, } \\
\text { weighted GLS }\end{array}$} \\
\hline & $\begin{array}{l}\text { Affirm } \\
\text { (1) }\end{array}$ & $\begin{array}{l}\text { Nonaff } \\
\text { (2) }\end{array}$ & $\begin{array}{l}\text { Negative } \\
\text { (3) }\end{array}$ & $\begin{array}{l}\text { Non Inv } \\
\text { (4) }\end{array}$ & $\begin{array}{l}\text { Affirm } \\
\text { (5) }\end{array}$ & $\begin{array}{l}\text { Nonaff } \\
(6)\end{array}$ \\
\hline $\begin{array}{l}\text { U.S. dollar price of } \\
\text { Canadian dollar * Period } \\
\text { before AD determination }\end{array}$ & $\begin{array}{l}-0.111 \\
(0.161)\end{array}$ & $\begin{array}{l}0.183 * * \\
(0.039)\end{array}$ & $\begin{array}{c}0.028 \\
(0.088)\end{array}$ & $\begin{array}{l}0.130 * * \\
(0.045)\end{array}$ & $\begin{array}{c}0.013 \\
(0.102)\end{array}$ & $\begin{array}{l}0.105^{* *} \\
(0.027)\end{array}$ \\
\hline $\begin{array}{l}\text { U.S. dollar price of } \\
\text { Canadian dollar * Period } \\
\text { during investigation }\end{array}$ & & & & & $\begin{array}{c}0.030 \\
(0.076)\end{array}$ & $\begin{array}{l}0.070 * * \\
(0.019)\end{array}$ \\
\hline $\begin{array}{l}\text { U.S. dollar price of } \\
\text { Canadian dollar * Period } \\
\text { after final determination }\end{array}$ & $\begin{array}{l}0.550 * * \\
(0.190)\end{array}$ & $\begin{array}{l}0.121 * * \\
(0.033)\end{array}$ & $\begin{array}{r}-0.095 \\
(0.079)\end{array}$ & $\begin{array}{c}0.075^{*} \\
(0.037)\end{array}$ & $\begin{array}{l}0.690 * * \\
(0.147)\end{array}$ & $\begin{array}{l}0.025 \\
(0.018)\end{array}$ \\
\hline $\begin{array}{l}(1+\mathrm{AD} \text { duty }) * \text { Period } \\
\text { during investigation }\end{array}$ & $\begin{array}{l}0.797 * * \\
(0.058)\end{array}$ & $\begin{array}{l}1.036^{* *} \\
(0.069)\end{array}$ & $\begin{array}{l}1.292 * * \\
(0.074)\end{array}$ & $\begin{array}{l}1.043 * * \\
(0.094)\end{array}$ & $\begin{array}{l}0.830 * * \\
(0.067)\end{array}$ & $\begin{array}{l}0.961^{* *} \\
(0.069)\end{array}$ \\
\hline $\begin{array}{l}(1+\mathrm{AD} \text { duty }) * \text { Period } \\
\text { after final determination }\end{array}$ & $\begin{array}{l}1.503 * * \\
(0.157)\end{array}$ & & & & $\begin{array}{l}1.560 * * \\
(0.156)\end{array}$ & \\
\hline $1+$ tariff & $\begin{array}{c}2.229 * \\
(1.117)\end{array}$ & $\begin{array}{l}2.668 * * \\
(0.284)\end{array}$ & $\begin{array}{l}5.019 * * \\
(0.496)\end{array}$ & $\begin{array}{r}2.274 * \\
(0.437)\end{array}$ & $\begin{array}{l}1.942 * * \\
(0.647)\end{array}$ & $\begin{array}{l}3.256^{* *} \\
(0.268)\end{array}$ \\
\hline Canadian producer costs & $\begin{array}{l}0.300 * * \\
(0.101)\end{array}$ & $\begin{array}{l}0.320 * * \\
(0.035)\end{array}$ & $\begin{array}{c}0.531 \\
(0.052)\end{array}$ & $\begin{array}{l}0.115^{*} \\
(0.045)\end{array}$ & $\begin{array}{l}0.274 * * \\
(0.104)\end{array}$ & $\begin{array}{l}0.299 * * \\
(0.035)\end{array}$ \\
\hline $\begin{array}{l}\text { U.S. domestic substitute } \\
\text { price }\end{array}$ & $\begin{array}{c}0.386 \\
(0.237)\end{array}$ & $\begin{array}{l}0.357 * * \\
(0.053)\end{array}$ & $\begin{array}{c}0.221 \\
(0.116)\end{array}$ & $\begin{array}{l}0.559 * * \\
(0.062)\end{array}$ & $\begin{array}{c}0.359 \\
(0.237)\end{array}$ & $\begin{array}{l}0.360 * * \\
(0.053)\end{array}$ \\
\hline U.S. expenditures on steel. & $\begin{array}{r}-0.098 \\
(0.079)\end{array}$ & $\begin{array}{r}0.021 \\
(0.020)\end{array}$ & $\begin{array}{c}0.039 \\
(0.039)\end{array}$ & $\begin{array}{c}0.017 \\
(0.025)\end{array}$ & $\begin{array}{c}-0.081 \\
(0.080)\end{array}$ & $\begin{array}{c}0.005 \\
(0.020)\end{array}$ \\
\hline $\begin{array}{l}\text { Canadian expenditures on } \\
\text { steel. }\end{array}$ & $\begin{array}{l}0.126^{* *} \\
(0.010)\end{array}$ & $\begin{array}{l}0.056^{* *} \\
(0.010)\end{array}$ & $\begin{array}{l}0.133 * * \\
(0.021)\end{array}$ & $\begin{array}{l}0.033 * * \\
(0.013)\end{array}$ & $\begin{array}{c}0.138 \\
(0.042)\end{array}$ & $\begin{array}{l}0.053 * * \\
(0.011)\end{array}$ \\
\hline Wald $\times^{2}$ statistic & $\begin{array}{r}4963.40 \\
* *\end{array}$ & $\begin{array}{r}1456510 \\
* *\end{array}$ & $\begin{array}{r}6472.52 \\
* *\end{array}$ & $\begin{array}{r}1415701 \\
* *\end{array}$ & $\begin{array}{r}5492.83 \\
* *\end{array}$ & $\begin{array}{r}1589994 \\
* *\end{array}$ \\
\hline Sample Size & 1008 & 7224 & 2604 & 4620 & 1008 & 7224 \\
\hline
\end{tabular}
imported steel product. All variables are in logarithms. For columns (1) through (4), the first row is the exchange rate coefficient for the period before the final determination, whereas for columns (5) and (6) it 
is the coefficient before the preliminary determination. Robust standard errors are in parentheses, with $* *$ and $*$ denoting statistical significance (two-tailed test) at the 1 and 5 percent levels, respectively.

\section{Appendix}

This appendix shows that elasticity of the price in the foreign market with respect to the exchange rate in the benchmark case may be higher or lower than that in case 1 or case 2 even when we assume that demand is linear in both the home and foreign market and there are constant marginal costs. In particular, assume demand in the foreign and home markets take the general linear form, $\mathrm{x}^{\mathrm{F}}=\mathrm{a}^{\mathrm{F}}-\mathrm{b}^{\mathrm{F}} \mathrm{p}^{\mathrm{F}}$ and $\mathrm{x}^{\mathrm{H}}=\mathrm{a}^{\mathrm{H}}-\mathrm{b}^{\mathrm{H}} \mathrm{p}^{\mathrm{H}}$, respectively. Also, assume the cost function for joint production of goods for both markets displays constant marginal costs and takes the form: $c\left(x^{\mathrm{F}}+\mathrm{x}^{\mathrm{H}}\right)=\mathrm{W} \mathrm{x}^{\mathrm{F}}+\mathrm{w} \mathrm{x}^{\mathrm{H}}$. We use the subscripts, $\mathrm{B}, 1$, and 2 , to denote prices in the benchmark case, case 1 and case 2 , respectively, and a "*" to denote equilibrium values of variables.

Substituting these functional forms into equation (1) of the paper, we can solve for the firm's optimal prices in terms of the parameters and show that the second-order sufficient conditions hold, provided both demand curves slope downward in price. Then, by the implicit function theorem, the elasticity of the foreign price with respect to the exchange rate in the benchmark model can be expressed as:

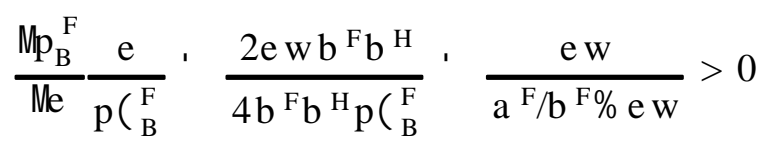

Likewise, we substitute the specific functional forms into equation (7) of the paper and solve for the effect of the exchange rate on the foreign price for case 1 as:

$$
\frac{\mathrm{M}_{1}^{\mathrm{F}}}{\mathrm{N}} \frac{\mathrm{e}}{\mathrm{p}\left({ }_{1}^{\mathrm{F}}\right.}{ }^{\prime} \frac{2 \mathrm{eb}^{\mathrm{F}} \mathrm{b}^{\mathrm{H}}\left(\mathrm{p}\left({ }_{1}^{\mathrm{H}} \% \mathrm{w}\right)\right.}{\left[4 \mathrm{~kb}^{\mathrm{F}} \mathrm{b}^{\mathrm{H}} \& \mathrm{e}\left(\mathrm{b}^{\mathrm{F}}\right)^{2}\right] \mathrm{p}\left(_{1}^{\mathrm{F}}\right.}>0
$$

where $\mathrm{k}^{\prime} \quad\left(2 \% \mathrm{t}_{0}^{\mathrm{AD}}\right) /\left(1 \% \mathrm{t}_{0}^{\mathrm{AD}}\right), \mathrm{p}_{1}^{\mathrm{H}}{ }_{1}^{\prime} \quad\left[\mathrm{k}\left(2 \mathrm{a}^{\mathrm{H}} \% \mathrm{a}^{\mathrm{F}} \% 2 \mathrm{wb} \mathrm{b}^{\mathrm{H}}\right) \% \mathrm{wb}^{\mathrm{F}}\right] /\left[4 \mathrm{~kb}^{\mathrm{H}} \& \mathrm{eb}^{\mathrm{F}}\right]$, and $\mathrm{p}\left(\begin{array}{c}\mathrm{F} \\ 1\end{array} \quad\left[2 \mathrm{ka}^{\mathrm{F}}\left(\mathrm{b}^{\mathrm{H}} / \mathrm{b}^{\mathrm{F}}\right) \% \mathrm{a}^{\mathrm{H}} \% 3 \mathrm{ew} \mathrm{b}^{\mathrm{H}}\right] /\left[4 \mathrm{~kb}^{\mathrm{H}} \& \mathrm{e} \mathrm{b}^{\mathrm{F}}\right]\right.$. It easy to show that the expression in (A1) is larger than the expression in (A2) for the parameter values: $\mathrm{a}^{\mathrm{F}}=\mathrm{a}^{\mathrm{H}}=3, \mathrm{~b}^{\mathrm{F}}=1, \mathrm{~b}^{\mathrm{H}}=2, \mathrm{w}=0.5, \mathrm{e}=1$ and $\mathrm{t}_{0}{ }^{\mathrm{AD}}=0.1$. On the other hand, one need to only change $\mathrm{b}^{\mathrm{H}}=1$ (instead of 2 ) to get the opposite result that the expression in (A2) is larger than the expression in (A1). Of course, the parameter values in both cases translate into nonnegative prices, quantities, and profits, and satisfy second-order sufficient conditions.

To compare the elasticity of the foreign price to the exchange rate in case 2 to the benchmark case, one can first derive the case 2 elasticity by substituting the specific functional forms and the equality, $\mathrm{p}^{\mathrm{H}}{ }^{\prime} \mathrm{p}^{\mathrm{F}} / \mathrm{e}\left(1 \% \mathrm{t}_{0}^{\mathrm{AD}}\right)$, into equation (1) of the paper. This yields

$$
\frac{\aleph_{2}^{\mathrm{F}}}{\mathrm{N}} \frac{\mathrm{e}}{\mathrm{p}\left(_{2}^{\mathrm{F}}\right.}, \frac{\&\left(2 \mathrm{~b}^{\mathrm{H}} \hat{\mathrm{k}}^{2}\right) / \mathrm{e} \&\left(\mathrm{ew} \mathrm{b}^{\mathrm{F}}\right) / \mathrm{p}\left({ }_{2}^{\mathrm{F}}\right.}{\& 2 \mathrm{~b}^{\mathrm{F}} \&\left(2 \mathrm{~b}^{\mathrm{H}} \hat{\mathrm{k}}^{2}\right) / \mathrm{e}}>0
$$

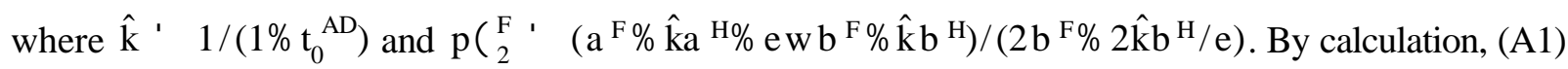


is larger than (A3) for parameter values: $\mathrm{a}^{\mathrm{F}}=\mathrm{a}^{\mathrm{H}}=3, \mathrm{~b}^{\mathrm{F}}=1, \mathrm{~b}^{\mathrm{H}}=0.2, \mathrm{w}=1, \mathrm{e}=1$ and $\mathrm{t}_{0}{ }^{\mathrm{AD}}=0.5$. In contrast, (A3) is larger for values: $\mathrm{a}^{\mathrm{F}}=\mathrm{a}^{\mathrm{H}}=3, \mathrm{~b}^{\mathrm{F}}=1, \mathrm{~b}^{\mathrm{H}}=0.3, \mathrm{w}=1, \mathrm{e}=1$ and $\mathrm{t}_{0}{ }^{\mathrm{AD}}=0.5$. Again, the parameter values translate into nonnegative prices, quantities, and profits for both cases. 


\section{Data Appendix}

To construct our dependent variable, monthly prices of imported iron and steel products at the 10digit Harmonized Tariff System (HTS) level, we first obtained U.S. Customs data on monthly customs value and quantity for iron and steel products by 10-digit HTS from 1989 through 1995 with the generous help of Michael Gallaway at the U.S. International Trade Commission (USITC). From these we constructed unit values by dividing customs value by quantity. To derive our dependent variable, we then multiplied these unit values by ( 1 + CUSFTAtar) and ( $1+$ ADduty), where CUSFTAtar denotes the ad valorem standard tariff rate that was applied to imports from Canada as negotiated by the Canada-U.S. Free Trade Agreement (CUSFTA) and ADduty is the ad valorem duty rate assessed on imported Canadian iron and steel products subject to preliminary and/or final U.S. antidumping (AD) duties from the steel cases filed in 1992. It should be noted that the CUSFTA, which went into effect on January 1 , 1989 - the beginning of our sample, involved gradual yearly reductions in the ad valorem tariff rate applied to the products in our sample. We obtained the standard ad valorem CUSFTA tariff rates by product from the NBER Trade Database Disk 1: U.S. Imports, 1972-1994 and from the Harmonized Tariff System, 1995, published by the USITC. We obtained information on the AD duties applied to Canadian iron and steel products from various Federal Register notices documenting the findings of the antidumping cases.

Monthly data on the U.S.-Canada bilateral exchange rate are official Bank of International Settlement end-of-month data defined in terms of U.S. dollars per Canadian dollar.

In order to proxy for factor prices for the Canadian steel exporting firms, we use monthly industrial product price indexes published in Statistics Canada, Industry Price Indexes, various issues. The following table gives the concordance we use to map Canadian industrial product price indexes (base $1986=100)$ to our HTS codes in iron and steel products.

Canadian industrial product price index 1992 HTS Product Codes
1) D691716
7217
2) $D 691718$
7213,7214
3) D691719
7215
4) D691723
7208.31 - 7208.33, 7208.42, 7208.43, 7211.21, 7211.22
5) $\mathrm{D} 691725$
6) D691726
$7210,7212,7216$, and 7211, except 7211.21 and 7211.22
7) D692843
8) D692844
7219
7208 , except those codes covered in 4) above
9) D693073
7209
10) $\mathrm{D} 693074$
11) D693075
7202
$7201,7203-7206,7218$
7207

Data for U.S. expenditures on iron and steel products was constructed as U.S. manufacturers' shipments of steel minus exports plus imports. Manufacturers' shipment data come from Manufacturers' Shipment, Inventories, and Orders: 1987-1996, published by Bureau of the Census, U.S. Department of Commerce, June 1997. The series we use is the seasonally unadjusted "Blast furnaces, steel mills". Recorded data on U.S. imports and exports of "iron and steel mill products" come from the Census web site: http://www.census.gov/foreign-trade/www/press.html\#prior. The Census 
web site had these data back to 1991, so data for 1989 and 1990 were taken from official published Census FT900 reports titled, U.S. Merchandise Trade.

Data for Canadian expenditures on iron and steel products were retrieved from the Statistics Canada online access to CANSIM data. Analogous to the U.S. expenditure data this variable is defined as Canadian steel manufacturers' shipments of steel minus exports plus imports. Monthly Canadian steel shipments include series D315529 (Primary steel industries) and D315534 (Iron foundries). Monthly import data include series D398024 (Steel bar, rods, plates and sheets) and D398025 (Other iron and steel products). Monthly export data include series D399265 (Steel bar, rods, plates and sheets) and D399264 (Other iron and steel products).

Data for the U.S. domestic substitute good price comes from monthly data on producer price indexes published by the U.S. Bureau of Labor Statistics (USBLS) and available from their website at: http://stats.bls.gov/ppihome.htm. The following table gives the concordance that maps appropriate USBLS producer price indexes to our HTS codes in iron and steel products.

USBLS price index

1) PCU3312\#2

2) PCU3312\#3

3) PCU3312\#4

4) PCU3312\#422

5) PCU3312\#5

6) PCU3312\#7

7) PCU3312\#8
1992 HTS product codes

$7201-7207,7218$ 7208, 7210, 7211.1, 7211.2, 7211.9, 7212,7219.1, 7219.2, 7219.3

7216, except parts of 7216.5 and 7216.6

7213,7214 , part of 7216.5

7217

7209, 7211.3, 7211.4, 7219.3

7215 , part of 7216.6 
To order any of these papers in hard copy, see instructions at the end of this list. To subscribe to all NBER Working Papers or the papers in a single area, see instructions inside the back cover.

\begin{tabular}{|c|c|c|c|}
\hline$\underline{\text { Number }}$ & Author(s) & Title & \\
\hline 7325 & $\begin{array}{l}\text { David Ikenberry } \\
\text { Josef Lakonishok } \\
\text { Theo Vermaelen }\end{array}$ & $\begin{array}{l}\text { Stock Repurchases in Canada: Performance and Strategic } \\
\text { Trading }\end{array}$ & $8 / 99$ \\
\hline 7326 & $\begin{array}{l}\text { Thomas C. Kinnaman } \\
\text { Don Fullerton }\end{array}$ & The Economics of Residential Solid Waste Management & $8 / 99$ \\
\hline 7327 & $\begin{array}{l}\text { Mark McClellan } \\
\text { Douglas Staiger }\end{array}$ & The Quality of Health Care Providers & $8 / 99$ \\
\hline 7328 & $\begin{array}{l}\text { John DiNardo } \\
\text { Mark P. Moore }\end{array}$ & $\begin{array}{l}\text { The Phillips Curve is Back? Using Panel Data to } \\
\text { Analyze the Relationship Between Unemployment and } \\
\text { Inflation in an Open Economy }\end{array}$ & $8 / 99$ \\
\hline 7329 & $\begin{array}{l}\text { Austan Goolsbee } \\
\text { Peter J. Klenow }\end{array}$ & $\begin{array}{l}\text { Evidence on Learning and Network Externalities in the } \\
\text { Diffusion of Home Computers }\end{array}$ & $9 / 99$ \\
\hline 7330 & $\begin{array}{l}\text { Young-Hye Cho } \\
\text { Robert F. Engle }\end{array}$ & $\begin{array}{l}\text { Time-Varying Betas and Asymmetric Effect of News: } \\
\text { Empirical Analysis of Blue Chip Stocks }\end{array}$ & $9 / 99$ \\
\hline 7331 & $\begin{array}{l}\text { Young-Hye Cho } \\
\text { Robert F. Engle }\end{array}$ & $\begin{array}{l}\text { Modeling the Impacts of Market Activity on Bid-Ask } \\
\text { Spreads in the Option Market }\end{array}$ & $9 / 99$ \\
\hline 7332 & Daniel S. Hamermesh & The Changing Distribution of Job Satisfaction & $9 / 99$ \\
\hline 7333 & James L. Heckman & $\begin{array}{l}\text { Causal Parameters and Policy Analysis in Economics: } \\
\text { A Twentieth Century Retrospective }\end{array}$ & $9 / 99$ \\
\hline 7334 & $\begin{array}{l}\text { Rajesh K. Aggarwal } \\
\text { Andrew A. Samwick }\end{array}$ & $\begin{array}{l}\text { Performance Incentives Within Firms: The Effect of } \\
\text { Managerial Responsibility }\end{array}$ & $9 / 99$ \\
\hline 7335 & $\begin{array}{l}\text { Rajesh K. Aggarwal } \\
\text { Andrew A. Samwick }\end{array}$ & $\begin{array}{l}\text { Empire-Builders and Shirkers: Investment, Firm } \\
\text { Performance, and Managerial Incentives }\end{array}$ & $9 / 99$ \\
\hline 7336 & $\begin{array}{l}\text { Richard Portes } \\
\text { Hélène Rey }\end{array}$ & The Determinants of Cross-Border Equity Flows & $9 / 99$ \\
\hline 7337 & Kathryn M. Dominguez & The Market Microstructure of Central Bank Intervention & $9 / 99$ \\
\hline 7338 & Jeffrey A. Frankel & $\begin{array}{l}\text { No Single Currency Regime is Right for all Countries } \\
\text { or at All Times }\end{array}$ & $9 / 99$ \\
\hline 7339 & Axel Börsch-Supan & $\begin{array}{l}\text { Incentive Effects of Social Security Under an Uncertain } \\
\text { Disability Option }\end{array}$ & $9 / 99$ \\
\hline
\end{tabular}

You can download these and other papers at the NBER Web site:

www.nber.org

Free searchable abstracts are also available at the site. 
To order any of these papers in hard copy, see instructions at the end of this list. To subscribe to all NBER Working Papers or the papers in a single area, see instructions inside the back cover.

$\underline{\text { Number }}$

Author(s)

7340

734

7342

7344

7345

7346

7347

7352

7353

7354
Hylke Vandenbussche

Jozef Konings

Linda Springael

Robert F. Engle

Simone Manganelli

David C. King

Richard J. Zeckhauser

Christina Paxson

Jane Waldfogel

Michael Hout

Harvey S. Rosen

Jean O. Lanjouw

Mark Schankerman

Geert Bekaert

Steven R. Grenadier

Thomas N. Hubbard

Jonathan Gruber

Edward P. Lazear

Tamim Bayoumi

Taizo Motonishi

Hiroshi Yoshikawa

Daron Acemoglu

Robert Shimer

Jeff Grogger

Charles Michalopoulos

Roberto Rigobon
Title

$\underline{\text { Date }}$

Import Diversion under European Antidumping Policy

9/99

CAViaR: Conditional Value at Risk By Quantile

$9 / 99$

Regression

Congressional Vote Options

$9 / 99$

Work, Welfare, and Child Maltreatment

$9 / 99$

Self-Employment, Family Background, and Race

$9 / 99$

The Quality of Ideas: Measuring Innovation with

Multiple Indicators

Stock and Bond Pricing in an Affine Economy

$9 / 99$

How Wide Is the Scope of Hold-Up-Based Theories?

Contractual Form and Market Thickness in Trucking

The Wealth of the Unemployed: Adequacy and Implications for Unemployment Insurance

Educational Production

$9 / 99$

The Morning After: Explaining the Slowdown in Japanese Growth in the 1990s

Causes of the Long Stagnation of Japan during the $9 / 99$ 1990's: Financial or Real?

Productivity Gains From Unemployment Insurance

Welfare Dynamics under Time Limits

On the Measurement of the International Propagation 9/99

You can download these and other papers at the NBER Web site:

www.nber.org

Free searchable abstracts are also available at the site. 
To order any of these papers in hard copy, see instructions at the end of this list. To subscribe to all NBER Working Papers or the papers in a single area, see instructions inside the back cover.

Number

7355

7356

7357

7358

7359

7360

7361

7362

7363

7364

7365

7366

7367

7368
Author(s)

Ricardo J. Caballero Mohamad L. Hammour

Alec Ian Gershberg Michael Grossman

Fred Goldman

Robert E. Lipsey

Vernon Henderson

Iain Cockburn

Rebecca Henderson

Scott Stern

Douglas Holtz-Eakin

John W. Phillips

Harvey S. Rosen

Bong-Chan Kho

René M. Stulz

Jagadeesh Gokhale

Laurence J. Kotlikoff

Bruce D. Meyer

Dan T. Rosenbaum

Dani Rodrik

Andrés Velasco

Michael D. Bordo

Lars Jonung

Emmanuel Saez

Emmanuel Saez

Alan L. Gustman

Thomas L. Steinmeier $\underline{\text { Title }}$

Date

The Cost of Recessions Revisited: A Reverse-

$9 / 99$

Liquidationist View

Competition and the Cost of Capital Revisited: Specia

$9 / 99$

Authorities and Underwriters in the Market for Tax-

exempt Hospital Bonds

Foreign Production by U.S. Firms and Parent Firm

$9 / 99$

Employment

Marshall's Economies

$9 / 99$

The Diffusion of Science-Driven Drug Discovery:

Organizational Change in Pharmaceutical Research

Estate Taxes, Life Insurance, and Small Business

$9 / 99$

Banks, the IMF, and the Asian Crisis

9/99

Social Security's Treatment of Postwar Americans:

$9 / 99$

How Bad Can It Get?

Welfare, the Earned Income Tax Credit, and the

$9 / 99$

Labor Supply of Single Mothers

Short-Term Capital Flows

$9 / 99$

The Future of EMU: What Does the History of

$9 / 99$

Monetary Unions Tell Us?

Do Taxpayers Bunch at Kink Points?

$9 / 99$

The Effect of Marginal Tax Rates on Income: A Panel 9/99 Study of 'Bracket Creep'

What People Don't Know About Their Pensions $9 / 99$ and Social Security: An Analysis Using Linked Data From The Health and Retirement Study

You can download these and other papers at the NBER Web site:

www.nber.org

Free searchable abstracts are also available at the site. 
To order any of these papers in hard copy, see instructions at the end of this list. To subscribe to all NBER Working Papers or the papers in a single area, see instructions inside the back cover.

\begin{tabular}{|c|c|}
\hline Number & Author(s) \\
\hline 7369 & $\begin{array}{l}\text { Wolfgang Keller } \\
\text { Arik Levinson }\end{array}$ \\
\hline 7370 & $\begin{array}{l}\text { Michael Baker } \\
\text { Gary Solon }\end{array}$ \\
\hline 7371 & $\begin{array}{l}\text { Michael Baker } \\
\text { Nicole M. Fortin }\end{array}$ \\
\hline 7372 & $\begin{array}{l}\text { B. Douglas Bernheim } \\
\text { Lorenzo Forni } \\
\text { Jagadeesh Gokhale } \\
\text { Laurence J. Kotlikoff }\end{array}$ \\
\hline 7373 & $\begin{array}{l}\text { Paul A. David } \\
\text { Bronwyn H. Hall } \\
\text { Andrew A. Toole }\end{array}$ \\
\hline 7374 & $\begin{array}{l}\text { Peter Cappelli } \\
\text { David Neumark }\end{array}$ \\
\hline 7375 & Charles I. Jones \\
\hline 7376 & $\begin{array}{l}\text { Harrison Hong } \\
\text { Jeremy C. Stein }\end{array}$ \\
\hline 7377 & $\begin{array}{l}\text { George Chacko } \\
\text { Luis M. Viceira }\end{array}$ \\
\hline 7378 & $\begin{array}{l}\text { Bruce A. Blonigen } \\
\text { Stephen E. Haynes }\end{array}$ \\
\hline
\end{tabular}

$\underline{\text { Title }}$

Date

Environmental Compliance Costs and Foreign Direct $\quad 9 / 99$ Investment Inflows to U.S. States

Earnings Dynamics and Inequality among Canadian

$9 / 99$ Men, 1976-1992: Evidence from Longitudinal Income Tax Records

Occupational Gender Composition and Wages in Canada: 9/99 1987-1988

The Adequacy of Life Insurance: Evidence from the $10 / 99$ Health and Retirement Survey

Is Public R\&D a Complement or Substitute for Private $10 / 99$ $\mathrm{R} \& \mathrm{D}$ ? A Review of the Econometric Evidence

Do "High Performance" Work Practices Improve $10 / 99$ Established-Level Outcomes?

Was an Industrial Revolution Inevitable? $10 / 99$ Economic Growth Over the Very Long Run

Differences of Opinion, Rational Arbitrage $10 / 99$ and Market Crashes

Dynamic Consumption and Portfolio Choice with $10 / 99$ Stochastic Volatility in Incomplete Markets

Antidumping Investigators and the Pass-Through of $10 / 99$ Exchange rates and Antidumping Duties

Copies of the above working papers can be obtained for $\$ 10.00$ per copy (plus $\$ 10.00$ per order for shipping for all locations outside the continental U.S.) to Working Papers, NBER, 1050 Massachusetts Avenue, Cambridge, MA 02138-5398. Pre-payment is required on all orders and may be made by check or credit card. Checks should be made payable to the NBER and must be in dollars drawn on a U.S. bank. If paying by credit card, include the cardholder's name, account number, and expiration date. For all orders, please be sure to include your return address and telephone number. Working papers may also be ordered by telephone (868-3900), fax (617-868-2742), or email (orders $(\dot{a}$ )nber.org).

You can download these and other papers at the NBER Web site:

www.nber.org

Free searchable abstracts are also available at the site. 